\title{
Integrated Test Plan ResonantSonic Drilling System Technology Demonstration-1995, at the Hanford Site
}

\section{DISCLAIMER}

This report was prepared as an account of work sponsored by an agency of the United States Government. Neither the United States Government nor any agency thereof, nor any of their employees, makes any warranty, express or implied, or assumes any legal liability or responsibility for the accuracy, completeness, or usefulness of any information, apparatus, product, or process disclosed, or represents that its use would not infringe privately owned rights. Reference herein to any specific commercial product, process, or service by trade name, trademark, manufacturer, or otherwise does not necessarily constitute or imply its endorsement, recommendation, or favoring by the United States Government or any agency thereof. The views and opinions of authors expressed herein do not necessarily state or reflect those of the United States Government or any agency thereof.

Prepared for the U.S. Department of Energy Office of Environmental Restoration and Waste Management

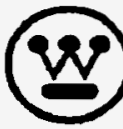
Westinghouse Hanford Company Richland, Washington

Hanford Operations and Engineering Contractor for the

U.S. Department of Energy under Contract DE-AC06-87RL10930 
WHC-SD-EN-TP-047, Rev. 1

Thịs page intentionally left blank. 


\section{DISCLAIMER}

Portions of this document may be illegible in electronic image products. Images are produced from the best available original document. 
CONTENTS

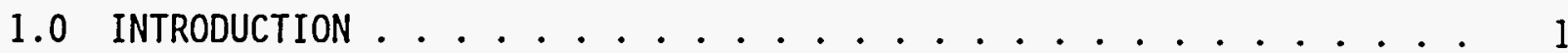

1.1 PURPOSE AND SCOPE . . . . . . . . . . . . . . 1

1.2 BACKGROUND ........................ 1

1.3 SITE SETTINGS ...................... 3

1.3.1 Hydrogeology and Subsurface Contamination ...... 6

1.3.2 Demonstration Test Locations ............ 8

2.0 TECHNOLOGY DESCRIPTION . . . . . . . . . . . . . 8

3.0 TEST OBJECTIVES AND MEASUREMENT CRITERIA . . . . . . . . . . 13

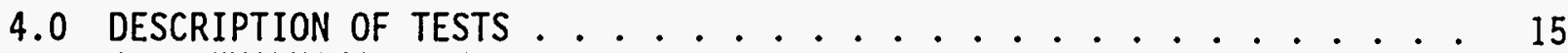

4.1 EVALUATION AND UPGRADES TO RESONANTSONIC SYSTEM . . . . . . 15

4.2 RESONANTSONIC DRILLING PARAMETER MEASUREMENT TEST . . . . . . . 15

4.3 SOIL VIBRATION AND DISPLACEMENT TEST . . . . . . . . . 15

5.0 REGULATORY AND HANFORD COMPLIANCE . . . . . . . . . . 17

5.1 NATIONAL ENVIRONMENTAL POLICY ACT . . . . . . . . . . . 17

5.2 GROUNDWATER WELL STANDARDS . . . . . . . . . . . . . 18

5.3 WASTE DISPOSITION . . . . . . . . . . . . . . 18

5.4 ONSITE PERMITS . . . . . . . . . . . . . 18

6.0 DEMONSTRATION SCHEDULE . . . . . . . . . . . . . 18

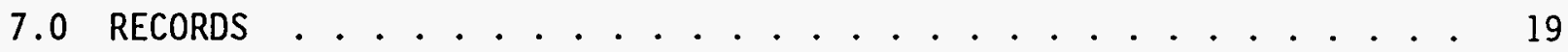

8.0 QUALITY ASSURANCE . . . . . . . . . . . . . 19

9.0 SAFETY .......................... 20

10.0 ORGANIZATION . . . . . . . . . . . . . . . 20

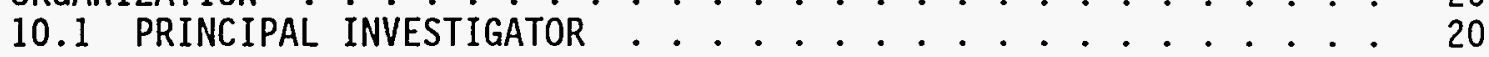

10.2 FIELD TEAM LEADER . . . . . . . . . . . . . . . 22

11.0 REFERENCES . . . . . . . . . . . . . . . . 22 APPENDICIES

A RESONANTSONIC DRILLING PARAMETER MEASUREMENT TEST PLAN . . . . . . A-1

B SOIL VIBRATION AND DISPLACEMENT TEST PLAN . . . . . . . . . . . . B-1

C RESONANTSONIC DEMONSTRATIONS SCHEDULE .............. C-1 
WHC-SD-EN-TP-047, Rev. 1

\section{FIGURES}

1 Hanford Site Map ....................... 2

2 ResonantSonic Drill - Vapor Extraction Angle Well VOC-ID ...... 4

3 Drilling Technology Test Site ............. 5

4 Geologic Cross-Section of Hanford 200 Areas Plateau . . . . . . . 7

5 In-Situ Bioremediation Demonstration Test Site ......... 9

6 In-Situ Well Stripping Demonstration Test Site ......... 10

7 ResonantSonic System . . . . . . . . . . . . . 11

8 ResonantSonic Drill Head . . . . . . . . . . . . . 12

9 ResonantSonic Data Acquisition System ............ 16

10 Organizational chart ................ 21 
WHC-SD-EN-TP-047, Rev. 1

\subsection{INTRODUCTION}

\subsection{PURPOSE AND SCOPE}

This integrated test plan describes the demonstration test of the ResonantSonic $\mathrm{cmll}^{\mathrm{sm}}$ drit7ing system. This demonstration is part of the office of Technology Development's Volatile Organic Compound Arid Integrated Demonstration (VOC-Arid ID). This follows two related feasibility tests conducted during periods of fiscal year (FY) 1991 through 1994. Two main purposes of this demonstration are (1) to continue testing the ResonantSonic drilling system compatibility with the Hanford Site waste site characterization programs, and (2) to transfer this method for use at the Hanford Site, other government sites, and the private sector.

\subsection{BACKGROUND}

Beginning in 1ate 1991, Harrison Western drilling from Lakewood, Colorado demonstrated the sonic drilling method at the Hanford Site. Field testing was - completed in May 1992. During the 10-month test, 8 groundwater wells, 1 vapor extraction we11, and 2 vadose zone wells were drilled; total footage was 938. These tests were conducted in various locations and geologies across the Hanford Site (Figure 1).

Results from this first test were compared to the Hanford Site baseline method, which is cable tool drilling. Drilling costs were reduced by $20 \%$, even though the downtime rate exceeded $50 \%$. Penetration rates were increased by $100 \%$. Waste minimization and contamination containment were comparable to the baseline technology. Core temperatures were slightly elevated, and drill pipe and drill head failures were frequent (Volk et al. 1992).

A.t though the sonic method exhibited significant potential, the high rate of component failures strongly indicated the need for further component and method refinements. As a result, a joint research effort with private industry was pursued through a Cooperative Research and Development Agreement (CRADA). The CRADA is structured around joint contributions from the U.S. Department of Energy (DOE) and the private industry partner(s).

While prospective industry partners were being evaluated in mid-1992, one drilling contractor's efforts to advance the sonic drilling technology was well established. Water Development Corporation (WDC) from Woodland, California had recently acquired a substantial portion of the Albert Bodine estate. (Bodine invented ResonantSonic drilling equipment.) Shortly thereafter, WDC also obtained virtually all of Harrison Western Drilling, Inc.'s sonic equipment. Subsequently, WDC assembled an expert staff of sonic drilling personnel.

\footnotetext{
${ }^{1}$ ResonantSonic is a service mark of the Water Development Corporation of Woodland, California.
} 
WHC-SD-EN-TP-047, Rev. I

Figure 1. Hanford Site Map.

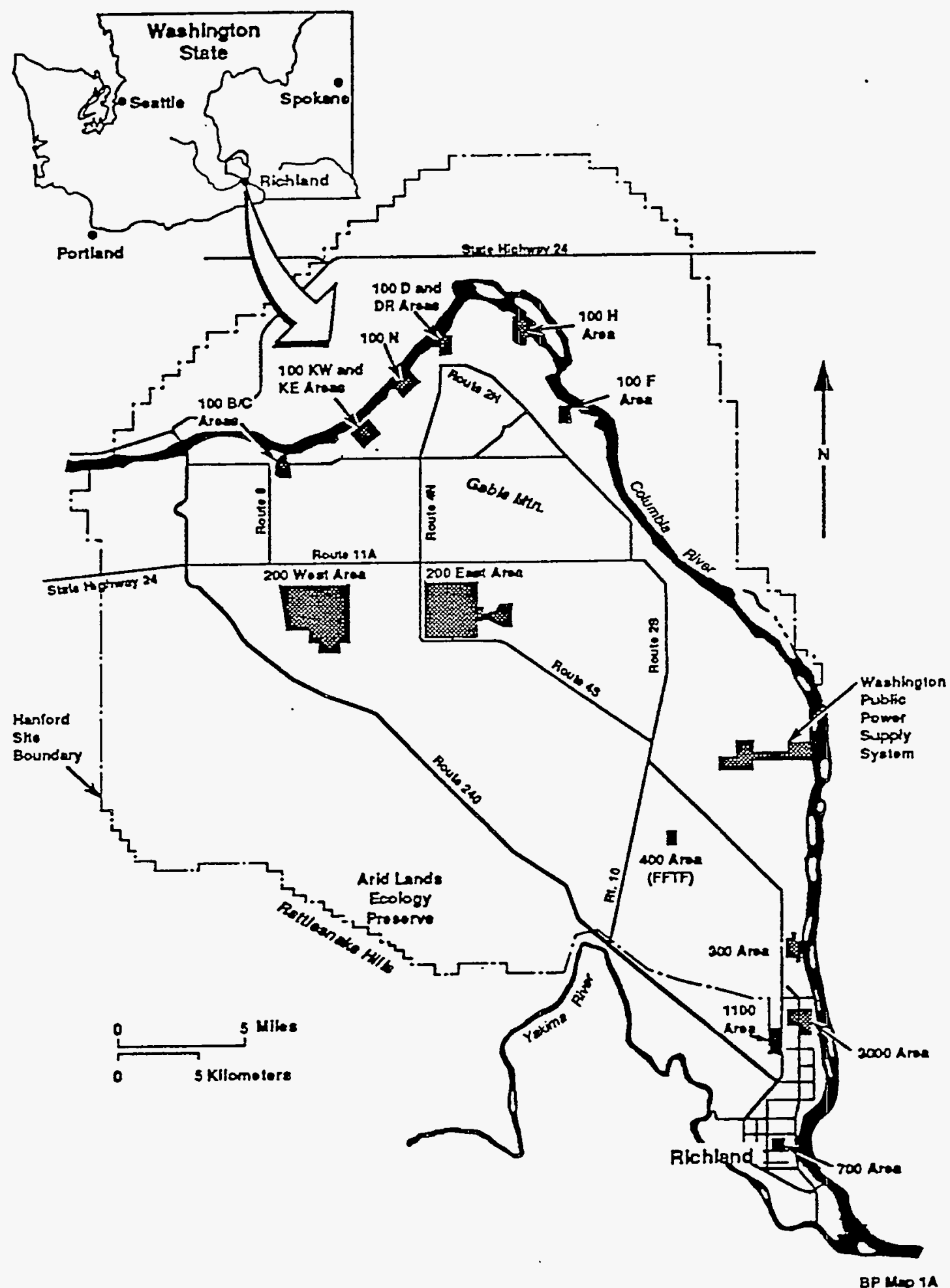


In February 1993, a CRADA was formed between WDC, Pacific Northwest Laboratory (PNL), and DOE to pursue further refinements to the sonic method and adapt the system for environmental applications. Westinghouse Hanford Company (WHC) was designated as the technical lead for the CRADA.

The ResonantSonic method is a dry drilling technique. Field testing of this method began in July 1993. During the next four months, nine holes were drilled, and continuous core samples were retrieved (total footage was 393 meters $[1,290$ feet $])$. Seven holes, 18 centimeters ( $65 / 8$ inches) in diameter, were drilled at a 45-degree angle. One angle hole was drilled to 51 meters (167 feet) and installed as a 7.6-centimeters (3-inch) diameter vapor extraction well at the VOC Arid-ID (Figure 2). A 22-centimeters (8 5/8-inch) diameter vertical test hole was drilled to 61 meters (200 feet), and an existing well was remediated and converted into a usable installation.

During the July to October (1993) timeframe, penetration rates were 2 to 3 times the baseline, and the operational downtime rate was less than $10 \%$ (compared to the 1991 to 1992 test rate, which was $>50 \%$ ). Reductions in soil sample $\left(\sim 15^{\circ} \mathrm{F}\right)$ temperatures were achieved on the vapor extraction well (average was $29.73^{\circ} \mathrm{C}\left[85.5^{\circ} \mathrm{F}\right]$ ). However, throughout the nine holes drilled, several elevated sample temperatures $\left(>38^{\circ} \mathrm{C}\left[>100^{\circ} \mathrm{F}\right]\right)$ were recorded. Ongoing efforts will be performed to further reduce core sample temperature.

Successfully demonstrated equipment refinements included a prototype 300 series ResonantSonic head, a new dril1 rod design for 18-centimeter (6 5/8-inch) diameter pipe, and an automated pipe handling system. Various configurations of sampling equipment and drill bits were tested, depending on geologic conditions.

The VOC-Arid ID is one of several DOE integrated demonstrations designed to support the development of environmental technologies. The principal objective of the VOC-Arid ID at the Hanford Site is to determine the viability of emerging technologies that can be used to characterize, remediate, and/or monitor arid or semiarid sites containing VOCs (e.g., carbon tetrachloride) with or without associated metal and radionuclide contamination. Initially, the VOC-Arid ID activities will focus primarily on the carbon tetrachloride contamination and associated contamination found in the 200 West Area.

\subsection{SITE SETTINGS}

Several field demonstrations using the ResonantSonic drilling method are planned during 1995. Locations in the 200 West Area include the In-Situ Bioremediation Test Site and the In-Situ Well Stripping Test Site. A separate test involving four shallow borings and installation of a flowmeter from Sandia National Laboratory will be conducted in the $100 \mathrm{H}$ Area. Three tests are planned at the Drilling Technology Test Site (DTTS) between the 200 East and 200 West Areas (Figure 3). These include: (1) instrumenting the ResonantSonic dri11 to measure drilling parameters and resonance levels in the drill pipe to support pipe design efforts, (2) a soil vibration test to determine the potential effects of ResonantSonic driliing on surrounding soils 
WHC-SD-EN-TP-047, Rev. 1

Figure 2. ResonantSonic Drill - Vapor Extraction Angle Well VOC-ID.
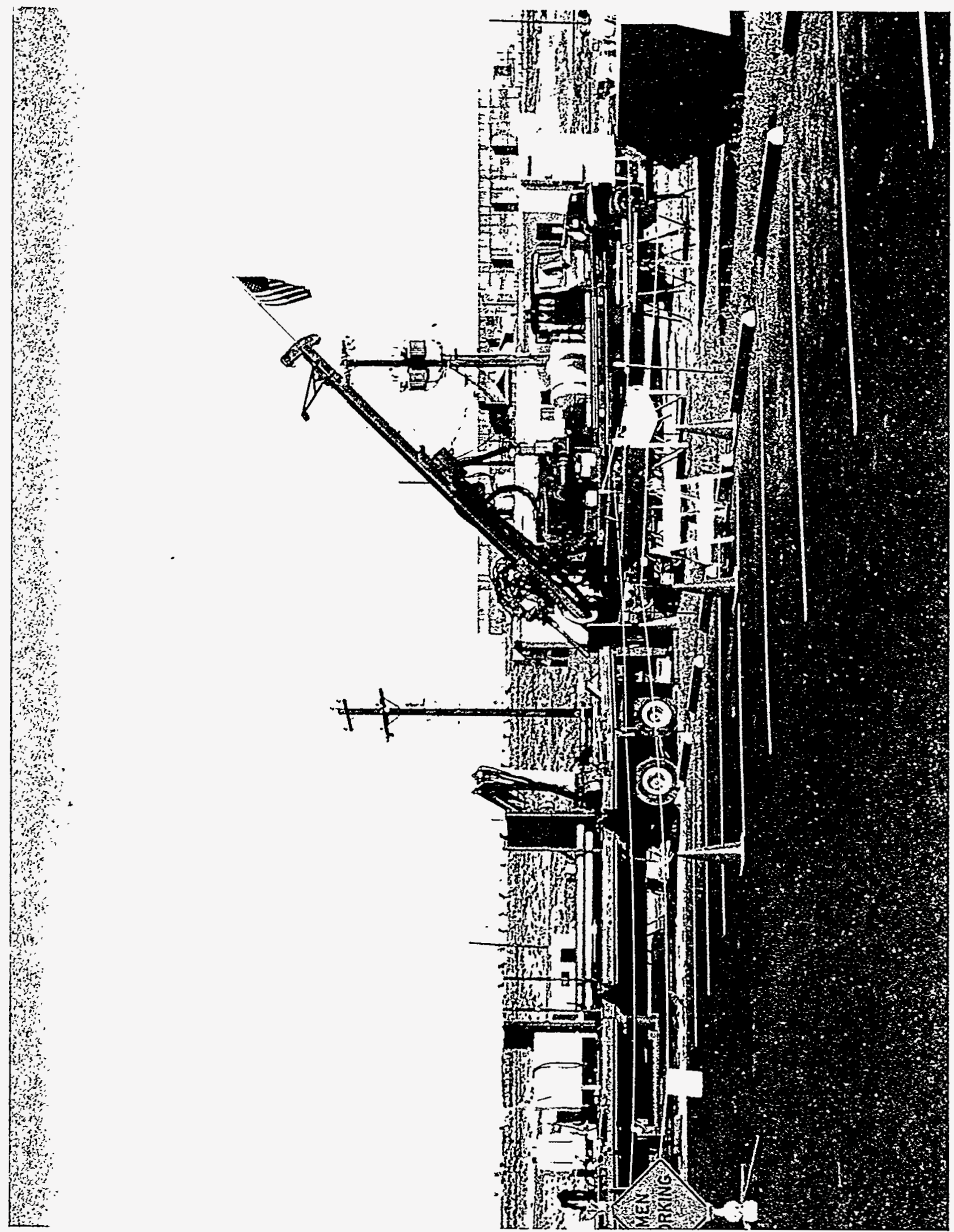
WHC-SD-EN-TP-047, Rev. 1

Figure 3. Drilling Technology Test Site.

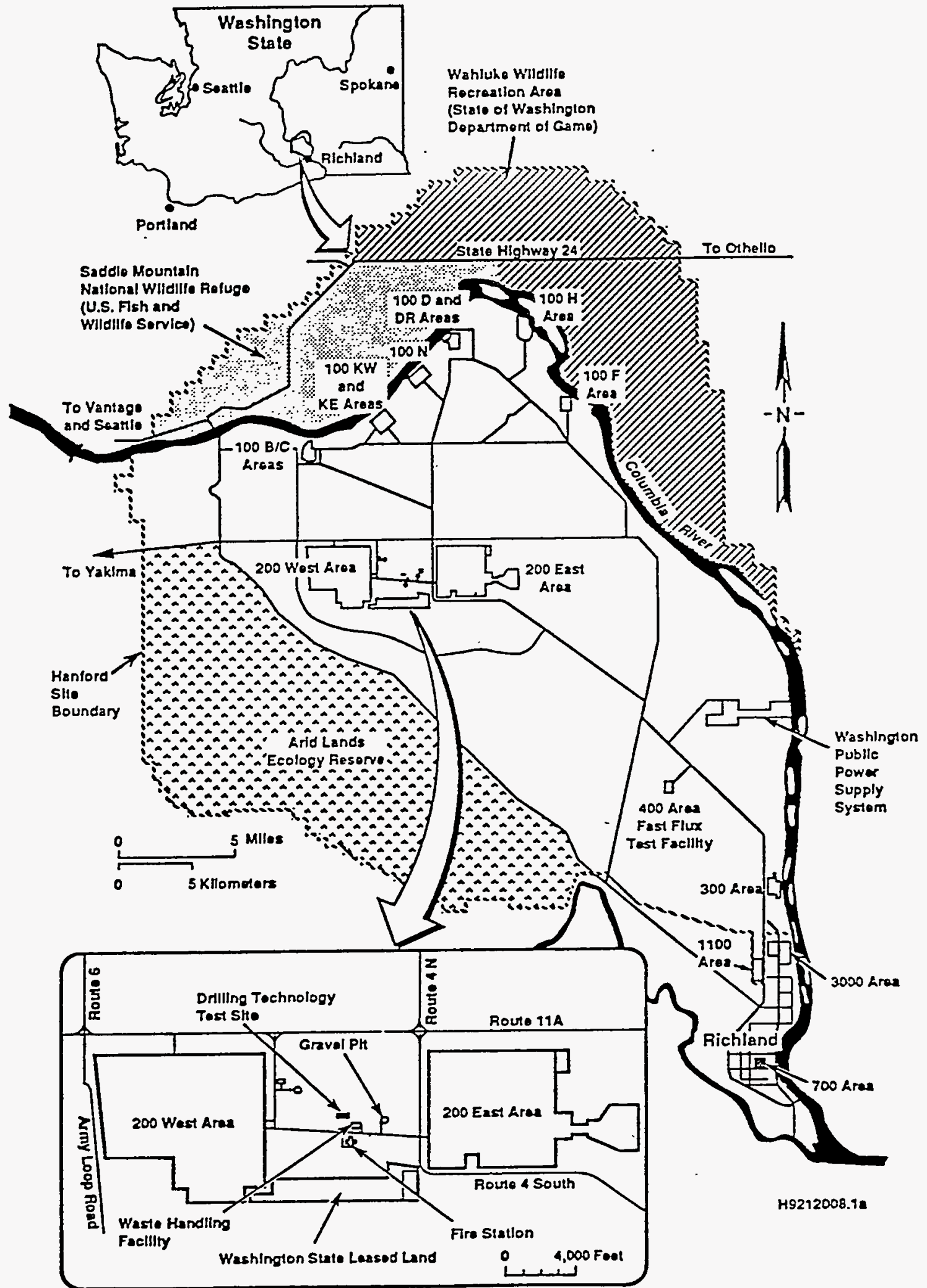


WHC-SD-EN-TP-047, Rev. 1

and structures, and (3) installing cone penetrometer rods with the ResonantSonic system to determine maximum depth capability (test target is 61 meters [200 feet]). Since the ResonantSonic drilling system is contracted, no drilling will occur in known radioactive sites.

\subsubsection{Hydrogeology and Subsurface Contamination}

Test locations in the 200 West Area are within the contaminant plume of three primary liquid waste disposal sites (216-Z-1A Tile Field, 216-Z-9 Trench, and the 216-Z-18 Crib) where carbon tetrachloride was disposed to the ground. These three sites received an estimated 363,000 to 580,000 liters $(95,895$ to 153,220 gal1ons) of carbon tetrachloride between 1955 and 1973, when ground disposal of carbon tetrachloride was terminated.

The unsaturated zone of the 200 West Area consists of fluvial and glaciofluvial sediments (Figure 4). The upper geologic unit, the Hanford formation, consists of two stratigraphic sequences: (1) a coarse-grained sequence consisting of interstratified gravel, sand, and lesser silt, and (2) a fine-grained sequence consisting of silt, silty sand, and sand interbedded with coarse sand. In the 200 West Area, the Hanford formation ranges in thickness from 6 meters to $>60$ meters $(19$ to $>196$ feet). It is underlain by up to 5 meters (16 feet) of unconsolidated silts and fine sands of the early Palouse soil, which in turn is underlain by up to 10 meters (33 feet) of a carbonate-rich paleosol (the Plio-Pleistocene unit). The higher degree of cementation and laterally continuous nature of this unit may create a layer with relatively low permeability. The Plio-Pleistocene unit is underlain by up to 6 meters (19 feet) of Ringold Formation fluvial sands and muds, which in turn are underlain by relatively well-compacted Ringold Formation fluvial gravels (Delaney et a1. 1991).

Carbon tetrachloride vapor concentrations observed during drilling throughout the 200 West Area in 1991 range from less than detectable to approximately 60 parts per million volume (ppm vol) in the unsaturated zone. The maximum observed concentrations in the immediate vicinity of the three carbon tetrachloride disposal sites are higher. For example, concentrations of carbon tetrachloride vapors measured in unsaturated zone boreholes within 30 meters (98 feet) of the three disposal sites ranged from 1 to $200 \mathrm{ppm}$ vol at depths of 24 to 63 meters (79 to 206.5 feet) below ground surface. Soil-gas concentrations as high as $6,000 \mathrm{ppm}$ vol were observed from a depth of 20 meters (65.5 feet) using a soil-gas probe near the $216-Z-9$ Trench.

However, the observed vapor concentrations may vary with time and appear to be influenced by fluctuations in the barometric pressure (DOE-RL 1991).

Carbon tetrachloride breakdown products, chloroform and methylene chloride, also have been observed in soil samples in trace amounts. Other substances that have been identified, in trace amounts, in at least one soil sample from the 200 West Area include benzene, fluoromethane, 1,1-dichloro-ethylene, 1,2-dichloroethylene, trichlorofluoromethane, methyl isobutyl ketone, and toluene (DOE-RL 1991). 
Figure 4. Geologic Cross-Section of Hanford 200 Areas Plateau.

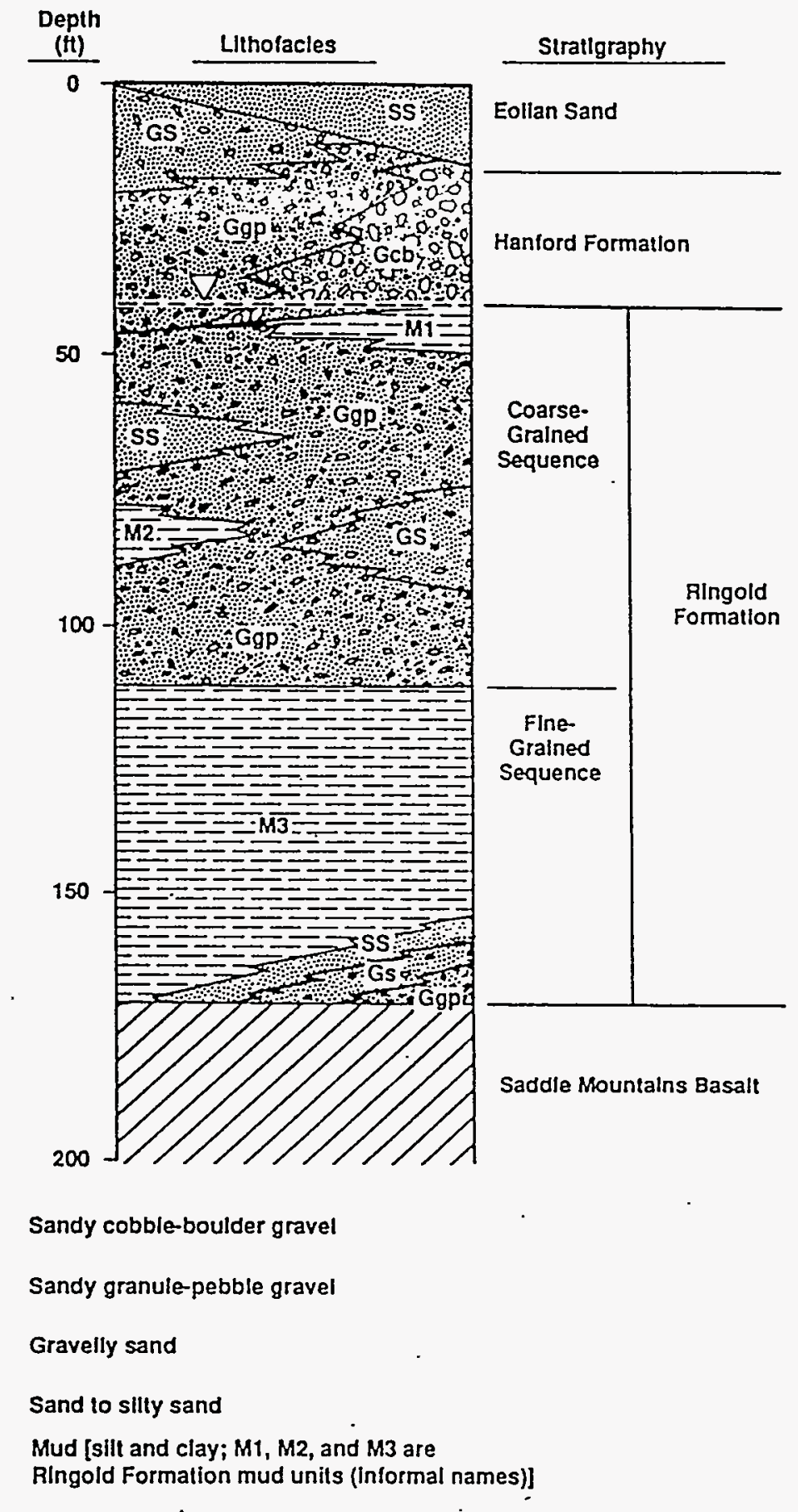


Many of the liquid waste streams discharged to the soil column in the 200 West Area since 1944 contain radionuclides. For example, the primary radionuclide components of the aqueous and organic liquids discharged to the three carbon tetrachloride disposal sites were plutonium and americium. The plutonium contamination extends approximately 30 meters ( $98 \mathrm{feet}$ ) beneath the 216-Z-1A Tile Field; the lateral spread is limited within a 9-meter(29.5 feet-) wide zone outside the perimeter of the tile field. Other radionuclides, such as radioactive isotopes of cesium, cobalt, hydrogen, iodine, strontium, and technetium, have been discharged to the soil column beneath the 200 West Area. In addition, radon gas occurs naturally in Hanford soils.

\subsubsection{Demonstration Test Locations}

The In-Situ Bioremediation Site is located approximately 76.2 meters (250 feet) north of the T-plant sanitary tile field and 229 meters ( 750 feet) west of 221-T plant. The location was chosen because it is downgradient from the cribs where $\mathrm{CCL}_{4}$ was disposed; groundwater samples indicate a fairly uniform $\mathrm{CCL}_{4}$ level near $2 \mathrm{ppm}$; nitrate is present at about $300 \mathrm{ppm}$ as a cocontaminant; and other co-contaminants are minimal (Figure 5). The ResonantSonic test will involve evaluating the system's capability to install 10 - to 15-centimeter (4- to 6-inch) well completions to depths of 97.5 to 104 meters ( 320 to 340 feet).

The In-We11 Stripping Demonstration Site is located approximately 213 to 244 meters (700 to 800 feet) north of the Plutonium Finishing Plant, between the 231-Z laboratory and the 216-Z-16 crib (Figure 6). The ResonantSonic system will be tested to determine ability to install one or two 20 - to 25-centimeter (8- to 10 -inch) well completions to approximately 91 meters (300 feet).

Testing will also occur at the DTTS, which is located near the 200 Areas Fire Station. Testing will occur primarily in the Hanford formation. Additional test locations in the 100 and 200 Areas may be selected depending on the performance of the ResonantSonic system and the opportunity to demonstrate feasibility for other environmental characterization and remediation applications.

\subsection{TECHNOLOGY DESCRIPTION}

The WDC ResonantSonic drilling system uses a combination of mechanically generated vibrations and rotary power to penetrate the soil (Figure 7). The oscillator, or drill head, consists of two counter-rotating rollers that cause the drill pipe to vibrate. The rollers are synchronized to ensure that the vertical force component is transmitted downward through the drill pipe or core barrel. The vibrations are isolated from the rig structure by an air spring (Figure 8).

The maximum displacements (elasticity) of the pipe occur when the drill pipe is in resonance. Resonance describes the condition when the frequency of 
Figure 5.' In-Situ Bioremediation Demonstration Test Site.

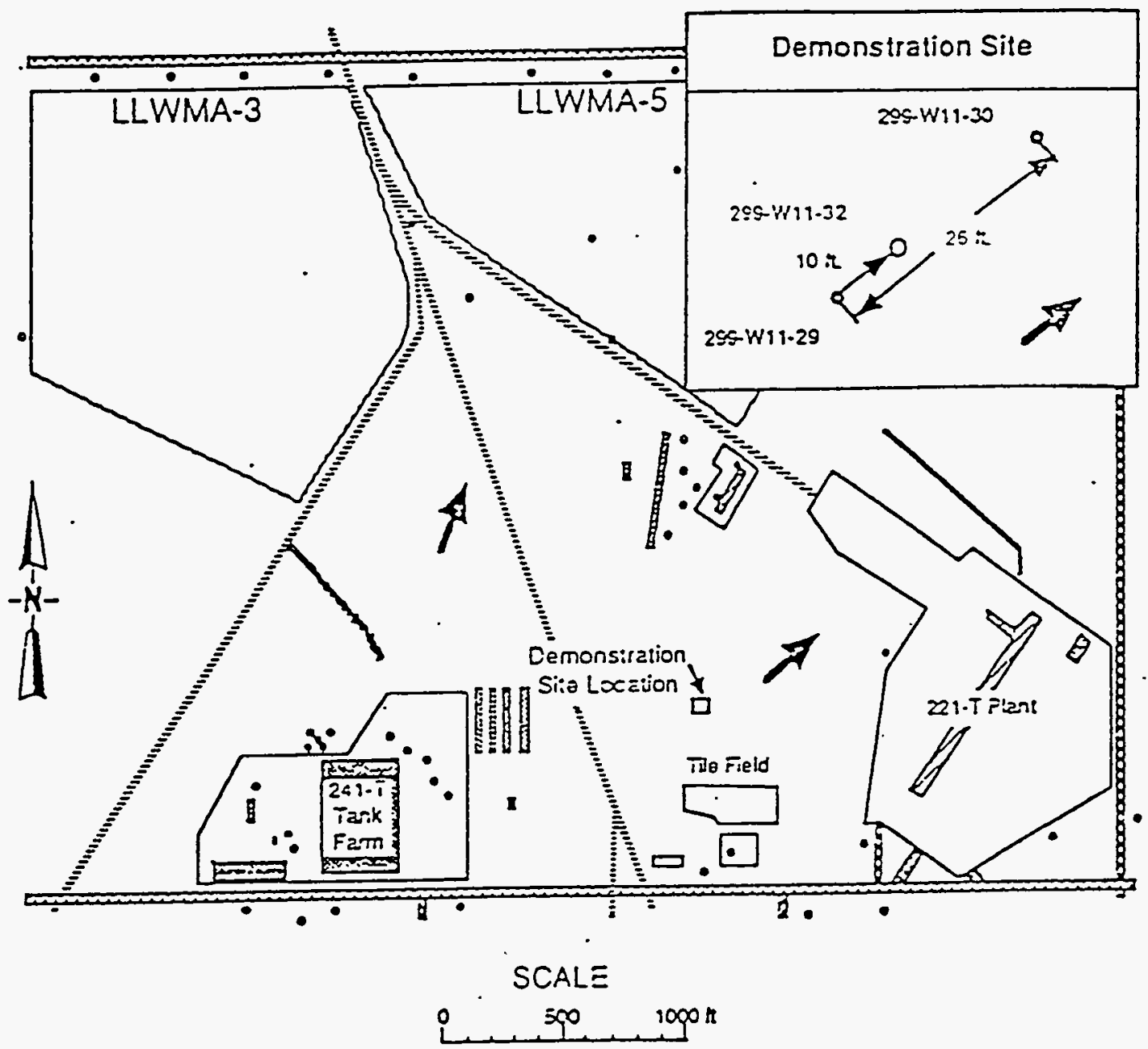

\begin{tabular}{|c|c|c|c|}
\hline \multicolumn{4}{|c|}{ EXPLANATION } \\
\hline 口 & $\begin{array}{l}\text { Demonstration Site } \\
\text { Exising Well Loczticns } \\
\text { Ground-water Flow Direcion }\end{array}$ & $=$ & $\begin{array}{l}\text { Inacive Disposal Facilties } \\
\text { Acive Disposal Facilties } \\
\text { Read } \\
\text { Failread }\end{array}$ \\
\hline
\end{tabular}


WHC-SD-EN-TP-047, Rev. 1

Figure 6. In-Situ Well Stripping Demonstration Test Site.

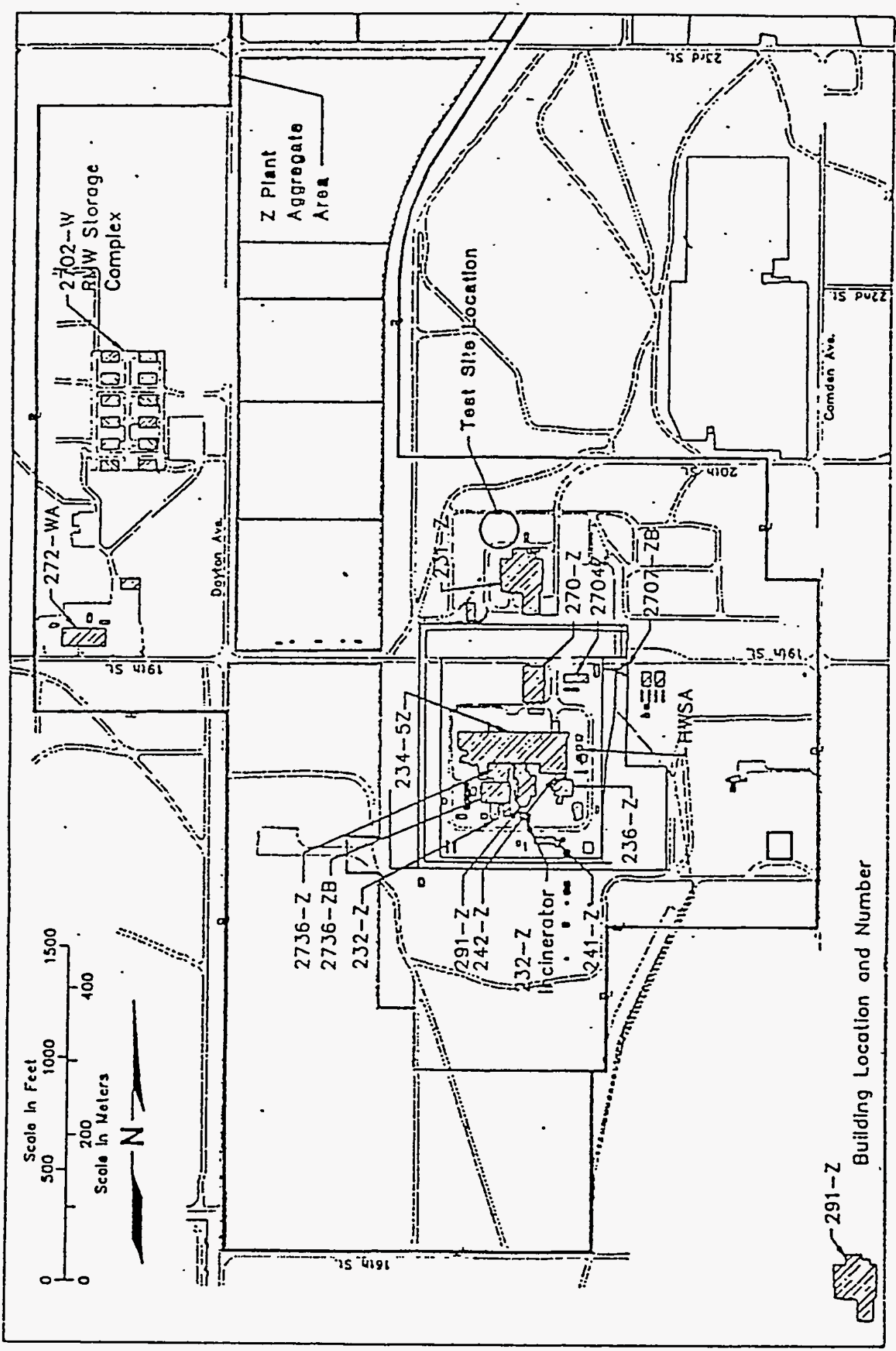




\section{ResonantSonic ${ }^{\text {sm }}$ Drilling Method}

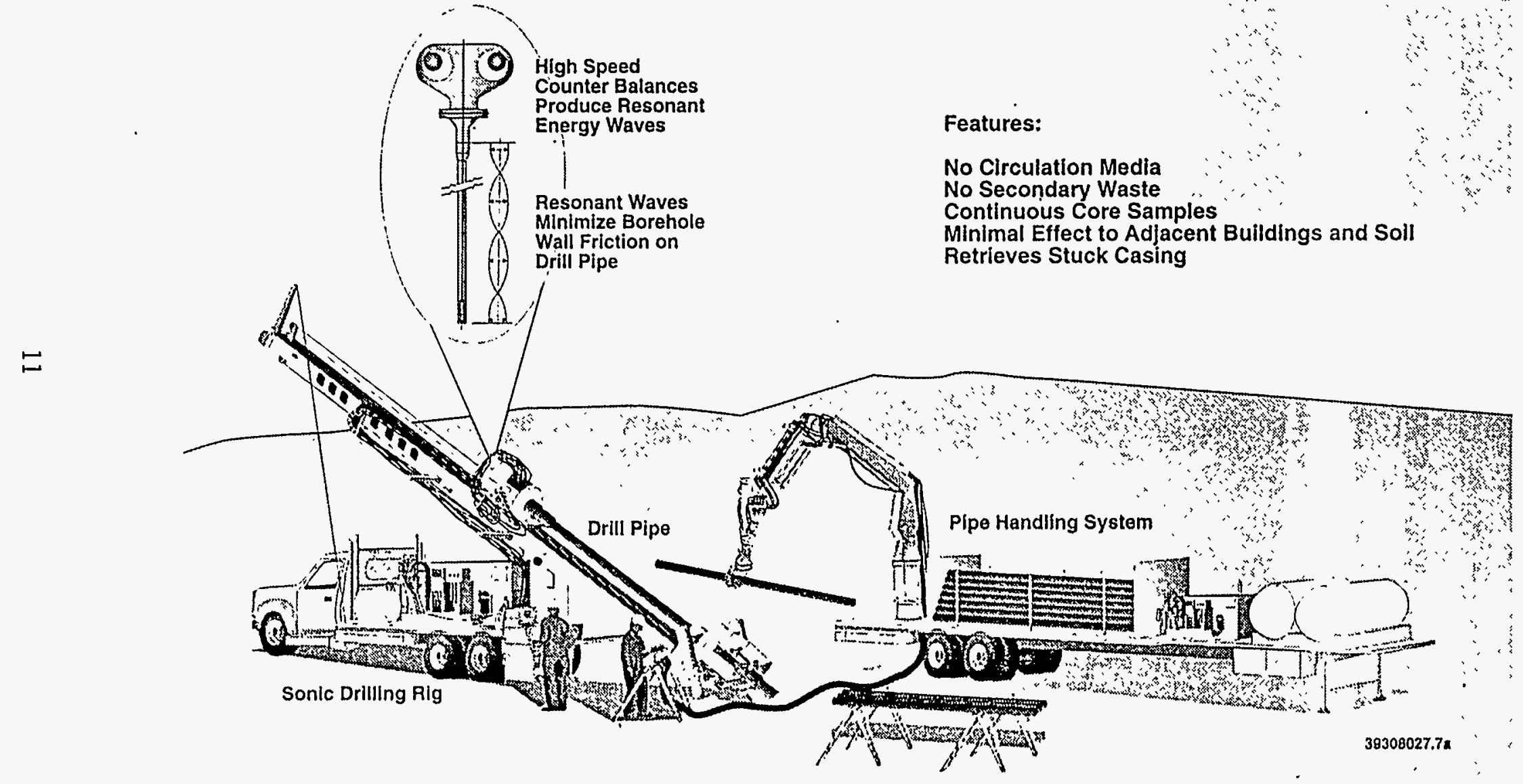


Figure 8. ResonantSonic Drill Head.

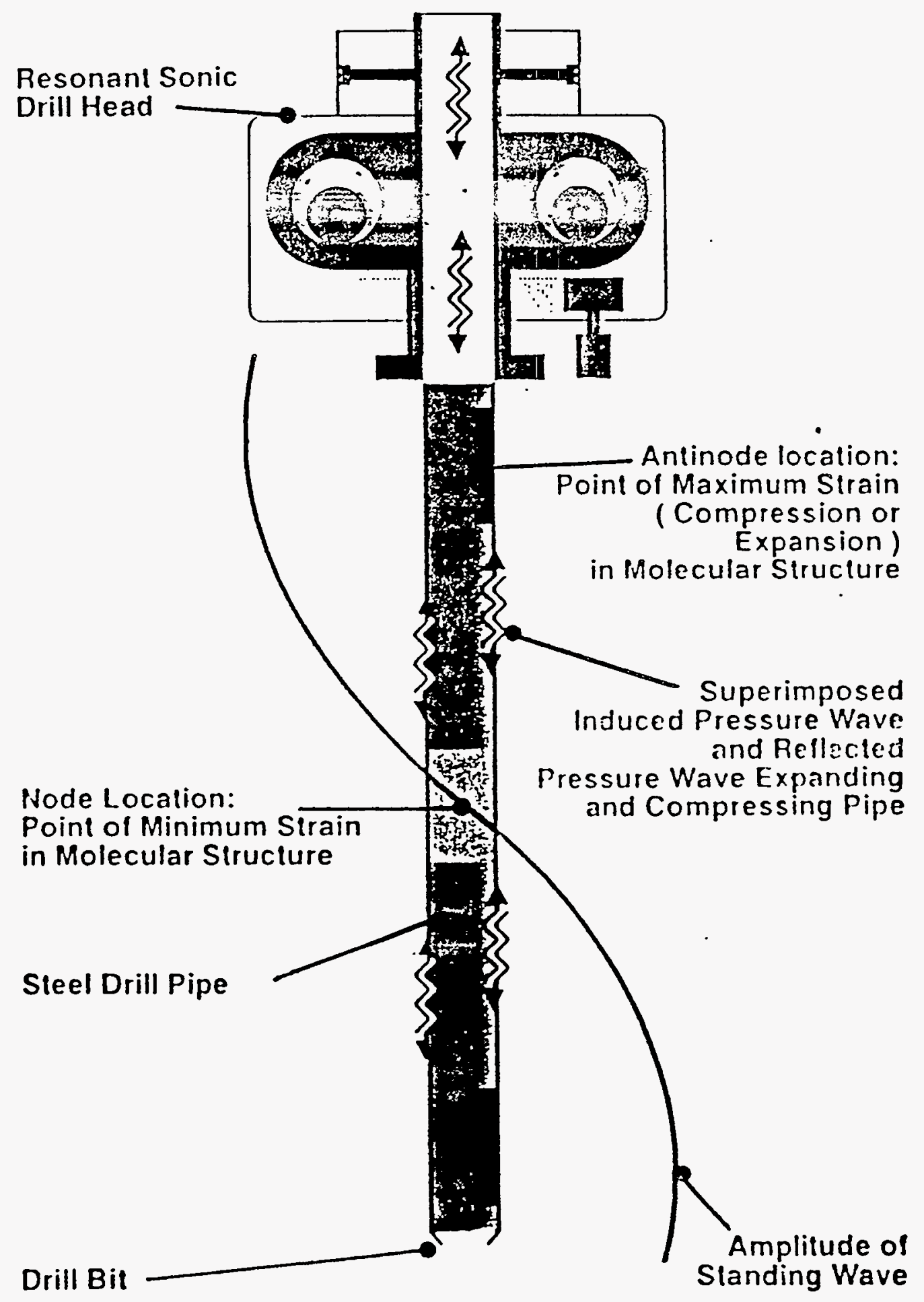


the vibrations equals the natural frequency of the drill pipe. The vibration of the drill pipe, coupled with the weight of the drill pipe and downward thrust of the drill head, allows penetration of the formation. Concurrent with the resonant energy, the drill head can be rotated to aid penetration. The vibrations generated in the drill string range from 0 to 150 hertz and create up to 21,773 kilograms $(48,000$ pounds) of force (when a $200 \mathrm{hp}$ input is used).

The vibrational component literally causes the formation to yield beneath the drill bit, so the drill string advances using minimal weight applied hydraulically with the drill head. The drill rig can generate a maximum of 4,536 kilograms ( 10,000 pounds) thrust; however, rapid penetration rates are commonly achieved with less than 454 kilograms (1,000 pounds) of downward thrust. The resonant energy emitted along the length of the drill pipe substantially reduces the amount of friction between the drill pipe and the borehole wall. In addition to drilling wells, the ResonantSonic method also has proven successful in extracting stuck drill pipe left by other drilling methods including cable-tool.

As the hole is advanced, additional sections of drill pipe (typically 1.5- to 3.1-meters [five- or ten-foot] lengths) are added. For sampling, the soil enters the driil string through an open-face (core-type) drill bit and is contained in an inner tube assembly. Removing the core samples requires withdrawing the drill pipe. To accomplish this, larger diameter casing is sequentially advanced over the drill pipe, which prevents borehole wall collapse during core retrieval. Penetration rates are rapid (typical drilling time for 3.1 meters [10 feet] is less than 3 minutes). Field tests will] include a removable casing plug developed by WDC to increase the productivity rate.

\subsection{TEST OBJECTIVES AND MEASUREMENT CRITERIA}

The primary purpose of the ResonantSonic CRADA task is to enhance the reliability and performance of the ResonantSonic drilling method. This will result in drilling operations that are faster, better, safer, and cheaper than the current baseline technology.

Testing of the ResonantSonic method during FY 1995 will expand on previous field tests in FY 1993. The primary emphasis for the CRADA tests are to demonstrate the ability to complete larger and deeper wells, maintain safe operations, decrease operational downtime, and increase operational efficiency and sample quality. Specific objectives are as follows.

OBJECTIVE 1: Test, evaluate, and select a preferred ResonantSonic drill pipe configurations.

Parameters: At least two configurations of drill pipe will be examined and compared based on the ability to drill up to 1,000 total feet (each string) without failure. Information will be collected and recorded in field activity reports for review and analysis. 
OBJECTIVE 2: Demonstrate operational efficiency and reliability of the ResonantSonic drill head in various geologic conditions.

Parameters: The ResonantSonic drill head down time per drilled hole will be recorded and maintained in the drilling field activity report.

OBJECTIVE 3: Demonstrate the ability to retrieve VOC soil samples with average temperatures not exceeding $80^{\circ} \mathrm{F}$.

Parameters: Core temperature data using calibrated temperature monitoring devices will be recorded at boreholes where samples are collected for VOC analysis. Average temperatures should not exceed $80^{\circ} \mathrm{F}$.

OBJECTIVE 4: Demonstrate compliance with Ecology regulations and well site construction standards for well completion. (WAC 173-160 and WHC-S-014, Generic Well Specifications.)

Parameters: Holes drilled with the ResonantSonic will completed and recorded in the field log report. All holes will be completed in accordance to the WAC $173-160$ and WHC-S-014 and a senior drilling engineer will verify.

OBJECTIVE 5: Compare cost effectiveness of the ResonantSonic drill with the cable-tool drill when used for detailed physical and chemical characterization of hazardous waste sites.

Parameters: The costs of the ResonantSonic drill will be recorded and maintained by the CRADA partner. These costs will be compared to the baseline cable tool drill for similar holes. This information will be presented in the Phase II CRADA report.

OBJECTIVE 6: Evaluate the effect of ResonantSonic drilling on nearby structures and buildings.

Parameter: A soil vibration test will be conducted to measure the resonant vibrations emanating from the ResonantSonic drill. Al1 information will be recorded by data loggers and reported in the Phase II CRADA report.

OBJECTIVE 7: Demonstrate safe operation of ResonantSonic dri11.

Parameters: The ResonantSonic will have a zero incident and injury record during all drilling activities. This will be documented in the site safety officers $\log$ book.

OBJECTIVE 8: Demonstrate the ResonantSonic method in various applications to determine possible uses to support environmental characterization and remediation activities.

Parameters: The ResonantSonic will drill 2 holes in both the vertical and angle $\left(45^{\circ}\right)$ modes at selected locations around the Hanford Site. 


\subsection{DESCRIPTION OF TESTS}

\subsection{EVALUATION AND UPGRADES TO RESONANTSONIC SYSTEM.}

Evaluations and refinements to ResonantSonic drilling components and subsystems will be performed. Foremost is the development of drill pipe strings for various sizes. The immediate focus is on 18 centimeters (6 5/8-inch) and 22 centimeters ( 8 5/8-inch) sizes, which are commonly used in the ResonantSonic drilling process for. installing 8- and 10-centimeter (3- and 4-inch) diameter wells. Supporting components to the drill pipe design process currently involve metallurgical analysis of materials, NDE examinations on products tested in the field, and computer modeling of thread configurations. Data collected will identify the dynamic forces to the drill string during the drilling process and assist in the material selection process for the drill pipe.

The sampling equipment purchased will depend on geologic conditions encountered, hole sizes drilled, and ongoing testing and refinement to drill bits. Core quality will be assessed as new components are tested. Core quality characteristics to bé considered include maintaining acceptable temperatures, maintaining physical properties, and containing VOCs. Other systems and components being evaluated for possible refinement include the ResonantSonic dri11 head and supporting hydraulic system, the automated rod handling system, and an automated decontamination system.

\subsection{RESONANTSONIC DRILLING PARAMETER MEASUREMENT TEST}

During FY 1993, an instrumentation system was developed for the Simco 300 ResonantSonic dri11 rig. During the first quarter of FY 1995, a field test will be conducted to record several operational parameters of the ResonantSonic system at selected operating levels. The primary purpose is to identify the resonant energy levels in the drill pipe during static and dynamic conditions (Figure 9). Data collected will be compared to drilling penetration results and maximum drill pipe tension and yield values. A control module with limit switches will be designed and tested during FY 1995. The ultimate goal is to optimize drilling parameters while maximizing drill pipe reliability. If successful, this system could provide an opportunity to distance personnel performing drilling and sampling at highrisk mixed-waste sites from the actual drilling operation, reducing their exposure to hazards. Specific details on the subject test activity are presented in Appendix A.

\subsection{SOIL VIBRATION AND DISPLACEMENT TEST}

Accumulate vibration data which shows the effects of the vibrations at specified distances from the ResonantSonic drill head. The accelerations in the soil will be measured in the $X, Y$, and $Z$ axes and stored in DOS files for future analysis. Two separate arrays of instruments will be used for comparison of the wave propagation through the soil if additional geotechnical analysis may become necessary in the future. 
Figure 9. ResonantSonic Data Acquisition System.

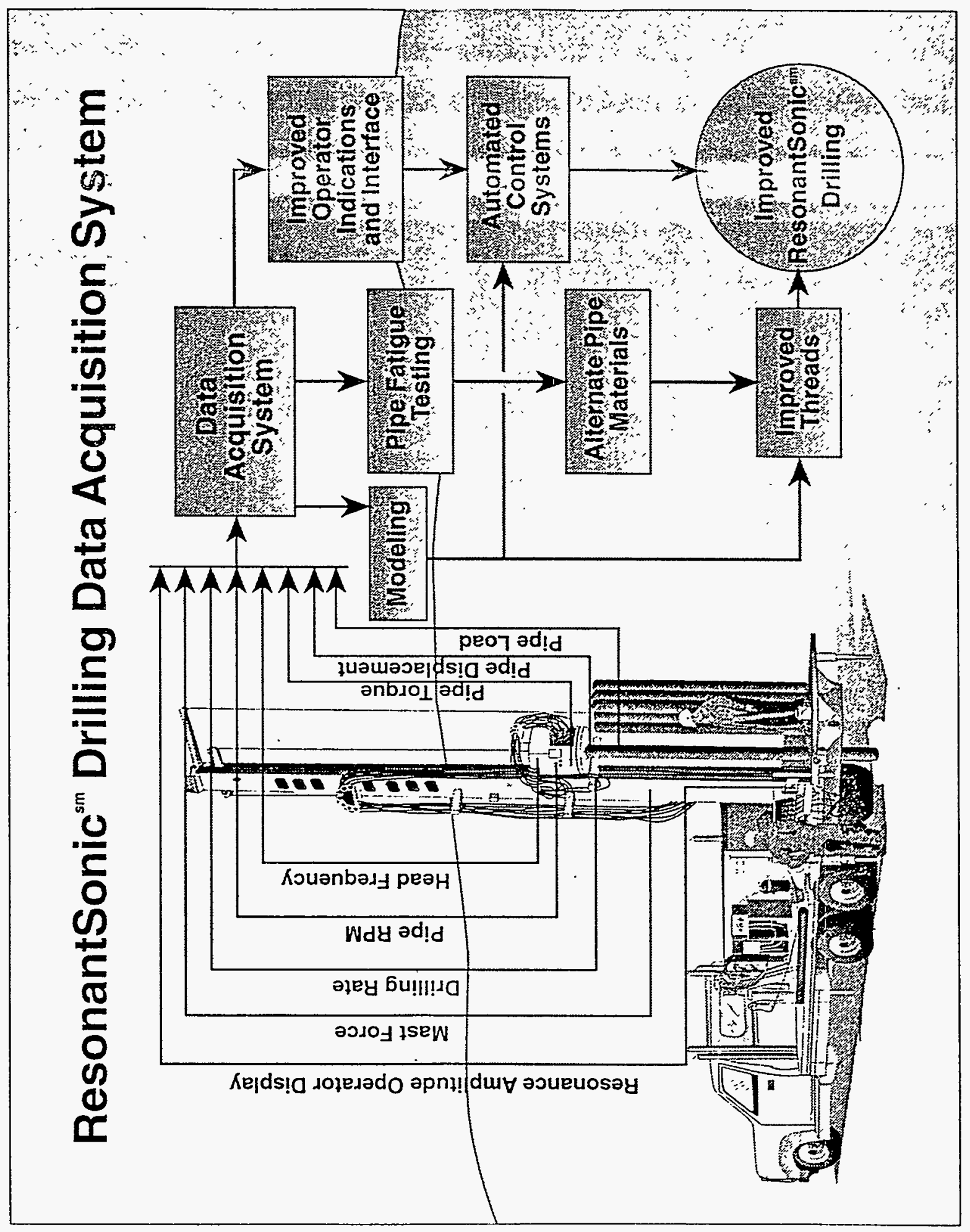


WHC-SD-EN-TP-047, Rev. 1

The final result will be files which have vibration data stored for each incremental distance from the array. This will allow variability on how close the ResonantSonic drill can be placed near the specific subsurface structure without causing damage to that structure. Additionally, horizontal and vertical soil displacements will be monitored and stored in data files.

Using the ResonantSonic drill rig, place two 4-inch casings down to 18 meters (60 feet) at the test site. Insert a specially designed instrument tree with 7 accelerometers at 10 foot intervals into the casing to the 18 meter (60 foot) depth. The leads and cables will be routed out the center of the tree arrangement. There will be two test stand holes drilled at the site for redundancy. Additionally, a third 18 meter (60 foot) hole will be drilled to supply instrumentation to measure horizontal and vertical displacements.

Cable wires will transmit information from the boreholes to a data acquisition system which will be set up in a mobile office trailer adjacent to the drill rig at the test site.

The test will consist of using the ResonantSonic dril1 to bore a series of vertical holes to a depth of 18 meters ( 60 feet) using a predetermined incremental distance while approaching the test array. At the predetermined incremental distances spectral data for from the ResonantSonic drilling method will be monitored and stored. Data will then be analyzed, condensed, and place data into usable computer files which are keyed to each drill hole (and respective location in the array). Specific details on the subject test are further delineated in Appendix B.

\subsection{REGULATORY AND HANFORD COMPLIANCE}

This section describes the regulations that apply to the conduct of this integrated test.

\subsection{NATIONAL ENVIRONMENTAL POLICY ACT (NEPA)}

The NEPA, 42 USC 4321-4370a, has been described by the Council on Environmental Quality as the basic federal charter for protecting the nation's environment. NEPA's purpose is to ensure that federal agencies such as DOE give appropriate consideration in their decision making to the potential environmental impacts of their actions. Compliance with NEPA for this continuing testing and demonstration of ResonantSonic drilling techniques is provided by a NEPA Categorical Exclusion (CX) for characterization and environmental monitoring activities on the Hanford Site that was approved by DOE on December 4, 1992 (Wagoner 1992). This ResonantSonic drilling demonstration is within the scope of the activities envisioned in that $C X$ approval for the following reasons. ResonantSonic drilling of the type to be demonstrated under this plan is one of the drilling techniques discussed in the Information Bullet in supporting that CX approval. While continued testing is the primary purpose of this ResonantSonic drilling demonstration, these activities will also produce data that will be useful for the characterization 
of the Hanford Site, which is the primary purpose of the activities for which the $C X$ was approved. The minimal impacts to the environment that will be caused by these testing and demonstration activities are clearly within the range of impacts assumed in DOE's CX approval. All permits and approvals mentioned in that $C X$ approval pertinent to these testing and demonstration activities including the performance of an ecological survey and cultural resources review for each of the testing and demonstration sites, will be obtained as noted in Section 5.4 below. Given that these ResonantSonic drilling testing and demonstration activities are covered by existing NEPA documentation, no further NEPA compliance documentation needs to be prepared for these activities.

\subsection{GROUNDWATER WELL STANDARDS}

Al1 ResonantSonic wells will be constructed in accordance with Washington Administrative Code (WAC) 173-160, "Minimum Standards for Construction and Maintenance of Wells."

\subsection{WASTE DISPOSITION}

Subtitle C of the Resource Conservation and Recovery Act of 1976 (RCRA), 42 USC 692l-6939b, establishes a comprehensive program to regulate newly generated hazardous waste. Administered by Ecology and EPA, RCRA Subtitle C requirements are contained in WAC 173-303 and in 40 CFR Parts 260 through 272 and apply to the generation, accumulation, treatment, storage, and disposal of hazardous waste. Any hazardous waste generated as a result of the activities described herein will be handled in accordance with Environmental Investigation Instruction (EII) 4.2, "Interim Control of Unknown, Suspected Hazardous, and Mixed Waste" (WHC-CM-7-7).

\subsection{ONSITE PERMITS}

Drilling and sampling will be conducted in accordance with the Environmenta 7 Investigations and Site Characterization Manual (WHC-CM-7-7). The specific procedure covering the drilling activities (EII 6.7, "Resource Protection Well Characterization and Evaluation") contains a checklist of permits and approvals reached prior to commencing field activities. All identified onsite permits will be in place and maintained as part of the record.

\subsection{DEMONSTRATION SCHEDULE}

The ResonantSonic system is currently drilling boreholes in the $100 \mathrm{H}$ Area for installing flowmeters developed by Sandia National Laboratory. Following the completion of this project the ResonantSonic drill will be used to drill four wells at the Bioremediation Integrated Demonstration Test Site. Three of the four wells are planned as 10-centimeters (4-inch) completions to approximately 91 meters (300 feet). The initial wel1, drilled as a test hole, 
to assess the performance of the drilling method to advance 22-centimeter (8 5/8-inch) drill pipe to depth. The drill pipe and casing strings for the first hole are a prototype design. Special design Resonantsonic drill pipe is being procured but will not arrive until the end of July. The number of bioremediation holes drilled prior to that time is dependant on the performance of the prototype dritl pipe.

Additional tests planned at the DTTS include a soil vibration test and a drilling parameter measurement test. Drill holes to support the In-Well Vapor Stripping Demonstrations Tests are contingent on the progress of other holes drilled for the Bioremediation Demonstration. Field tests during 1995 will focus on the performance of larger diameter drill pipe, sample temperatures, optional drilling processes, and pushing cone penetrometer rods to 69 meters (225 feet). The drilling schedule is shown in Appendix C.

\subsection{RECORDS}

Data collected by the Operations Team in support of the technology demonstration and testing will comply with EII 1.6, "Records Management" (WHC-CM-7-7).

The Operations Team will prepare and submit a data package to the principal investigators. At the end of the test, the Operations Team will prepare and submit to the VOC-Arid ID Management Team. All data generated will be revised and included in the "ResonantSonic Phase II CRADA" report.

Principal investigators and peer reviewers will evaluate test data. Reviewers will be assigned in accordance with their respective expertise.

Drilling data will be documented per EII 6.7, "Activity Reports of Field Operations." Sample quality and descriptions will be documented in accordance with EII 9.1, "Geologic Logging" (WHC-CM-7-7). Cost data will be provided from both Kaiser Engineers Hanford and WHC financial databases.

ResonantSonic drilling will be performed in accordance with WDC's operating procedures. The associated SAP, QAPP, and Data Management Plan for the data collected as part of the In-Situ Bioremediation Demonstration and the In-Situ Well Stripping Demonstration are found in site work plans for these programs.

\subsection{QUALITY ASSURANCE (QA)}

The objective of the test plan and the appendices is to ensure that the data obtained and the conclusions drawn are sufficiently accurate and reliable to support decisions associated with the evaluation of the demonstration. Instrumentation to support planned field tests will be calibrated. Specific items calibrated and related frequencies are noted in the respective appendixes noted in Sections 4.2 and 4.3 . 
To ensure that the objectives of the test are met, work will be performed in compliance with Quality Assurance, (WHC-CM-4-2) and with the procedures outlined in the QA program plan (WHC 1990) specific to CERCLA RI/FS and RCRA-related activities. This QA program plan describes the various plans, procedures, and instructions that will be used by Westinghouse Hanford to accomplish this demonstration test.

\subsection{SAFETY}

Safety activities conducted during drilling and sampling will be governed by site health \& safety plans (EII 2.1) and/or hazardous waste operations permits. Health physics technicians and site safety officers will monitor for contamination as directed by the approved plans. A hazards classification of the activities covered in this test plan determined that they are in a general-use category (Lehrschall 1992).

Access to the work site will be controlled by the field team leader. Training requirements are outlined in applicable health and safety plans for the individual demonstrations.

\subsection{ORGANIZATION}

General roles and responsibilities specific to this field demonstration are delineated below (Figure 10). The demonstration will be performed by Demonstration Operations of the VOC-Arid ID and the principal investigator. Demonstration Operations is responsible for characterization, engineering and conduct of field activities and for compliance with regulations and DOE-RL orders.

\subsection{PRINCIPAL INVESTIGATOR}

The Principal Investigator will do the following:

- Ensure that the test objectives are met

- Conduct the testing through coordination with the field team leader

- Provide all equipment to be tested

- Provide personnel to set up equipment, perform the test, and analyze the results

- Prepare a performance evaluation report that reviews the results of the testing related to each demonstration. 
WHC-SD-EN-TP-047, Rev. 1

Figure 10. Organizational Chart.

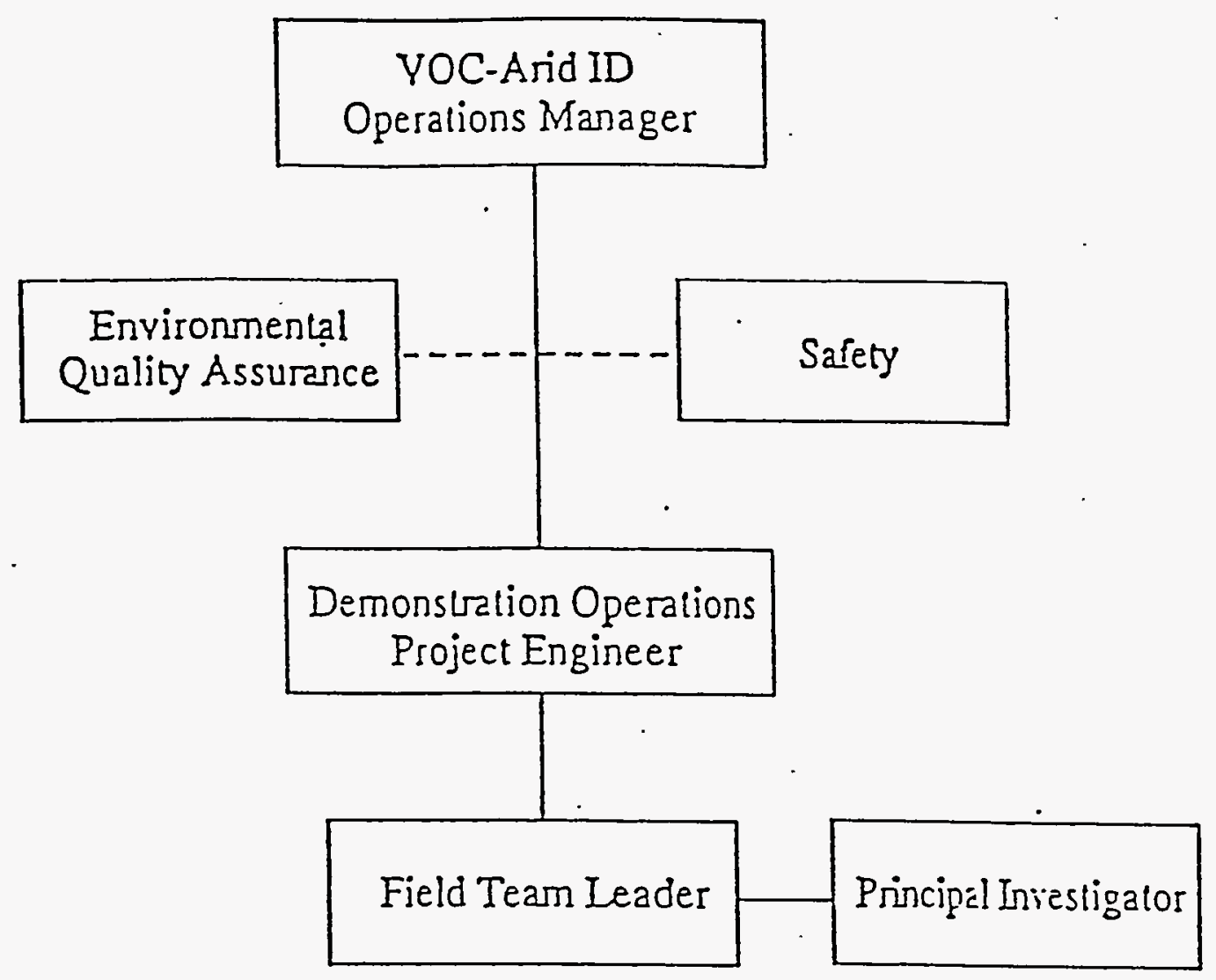




\subsection{FIELD TEAM LEADER}

The field team leader is responsible for overall technical field management of the project and controls onsite access. All onsite personnel report through the field team leader to accomplish work. The field team leader is supported independently by health and safety personnel and health physics technicians monitoring for potential radiological contamination.

\subsection{REFERENCES}

DOE-RL, 1991, Expedited Response Action Proposa7 (EE/CA \& EA) for 200 West Area Carbon Tetrachloride Plume, DOE/RL-91-32, Draft B, U.S. Department of Energy, Richland Field Office, Richland, Washington.

Delaney, C. D., K. A. Lindsey, S. P. Reidel, 1991, Geology and Hydrology of the Hanford Site: A Standardized Text for use in Westinghouse Hanford Company Documents and Reports, WHC-SD-EN-TI-003, Rev. 1, Westinghouse Hanford Company, Richland, Washington.

Lehrschal1, R. R., 1992, Safety Assessment for. Drilling New Characterization Boreholes in the 200 West Area, WHC-SD-EN-SAD-007, Rev. 0, Westinghouse Hanford Company, Richland, Washington.

Wagoner, J. D., 1992, National Environmental Policy Act (NEPA) Categorical Exclusion (CX) Determination: Site Characterization and Environmental Monitoring, Hanford Site, Richland, Washington (external letter 9208799 to C. M. Borgstrom, DOE-HQ, December 4, 1992 from DOE-RL), Westinghouse Hanford Company Operations, Richland, Washington.

WHC-CM-7-7, Environmental Investigations and Site Characterization Manual, Westinghouse Hanford Company, Richland, Washington.

WHC-CM-4-2, Quality Assurance, Westinghouse Hanford Company, Richland, Washington.

WHC, 1990, Environmental Engineering, Technology, and Permitting Function Quality Assurance Program Plan, WHC-EP-0383, Westinghouse Hanford Company, Richland, Washington.

Volk, B. W., G. W. Mclellan, and V. L. King, 1992 Results of Testing the Sonic Drilling System at the Hanford Site (September 1991 through May 1992), WHC-SD-EN-TRP-002, Rev.0, Westinghouse Hanford Company, Richland, Washington. 
WHC-SD-EN-TP-047, Rev. 1

APPENDIX A

RESONANTSONIC DRILLING PARAMETER MEASUREMENT TEST PLAN

D. M. Squier

A-1 
WHC-SD-EN-TP-047, Rev. 1

This page intentionally left blank. 


\subsection{INTRODUCTION}

A ResonantSonic drill creates longitudinal resonant vibrations in a drill pipe string. The vibrations are transferred to the soil surrounding the drill pipe causing the soil to behave like a fluid. The fluidized soil allows the drill string to penetrate the ground at greater rates than possible by conventional means.

The ResonantSonic drilling technique does not require a cutting fluid as with other methods. This reduces the waste generated and the migration of hazardous materials in contaminated areas. ResonantSonic drilling offers the potential for significant cost savings in the characterization and clean up of hazardous waste sites.

ResonantSonic drilling has been in use since the 1960's. Wider use of this drilling technique has been stymied by frequent failures of the threads used to join sections of the drill string. The dynamics and loads imposed on the drill string are not very well understood. The drill rig operator has only rudimentary instrumentation that does not provide an indication of the drill string's resonant condition. A skilled operator specially attuned to this drilling method is required.

A drill rig will be instrumented to gain a better understanding of the drilling parameters that contribute to effective drilling and improve the life of the drill string. The output of the instruments will be recorded and drive a graphical display for the operator. The operator display will provide the following indications:

- Oscillator $\mathrm{Hz}$

- Drilling rate

- Torque on the drill string

- Drill string RPM

- Mast pulldown force

- Oscillator horsepower

- User selectable frequency spectrum of the axial drill string load, drill string acceleration or drill string displacement.

\subsection{INSTRUMENTATION}

The instrument leads must follow a long path to accommodate the motions of the ResonantSonic head. The majority of the instruments will have three wire 4 to $20 \mathrm{ma}$ outputs to overcome the problem of noisy signals associated with long lead lengths.

The data will be recorded in blocks that include single value inputs and waveform inputs. Some single value inputs are derived from the average of a number of points. Below are listed the single value inputs.

- Relative time in milliseconds

- Oscillator $\mathrm{Hz}$ 


$$
\text { WHC-SD-EN-TP-047, Rev. } 1
$$

- Average mast force

- Average pressure drop across the oscillator motor.

- Average drill string torque

- Drill string RPM.

The waveform inputs are recorded as a power of two set of points. The power of two number of points facilitates the extraction of the frequency spectrum by the fast Fourier transform algorithm. The waveform inputs are listed below.

- ResonantSonic head axial force output

- Drill string acceleration

- Drill string displacement

- Oscillator roller position.

The roller position output is not a waveform but a pulse that is generated each time the oscillator roller passes a reference position. This data will determine the phase of the waveform inputs relative to the roller position.

\subsection{CALIBRATION RECORDS}

Copies of all calibration records will be kept in a laboratory notebook devoted to the instrumented ResonantSonic drill rig. The test report will contain a Measuring and Test Equipment list as well as documentation of all calibration records. These records shall identify the following items:

- Calibration standard

- Calibration date

- Person performing the calibration

- Manufacturer and model number of the instrument

- Serial number of the instrument

- Calibration method

- Slope and offset factors used by the data acquisition system to obtain engineering units.

The slope and offset values will be determined by a least squares fit of the calibration data. The instruments will be calibrated as a system where possible. A system shall include the instrument, the power supply, the signal conditioner and the data acquisition system. Calibration as a system will account for the acuminated errors developed by each component of the system.

The calibration of some instruments may be checked in the field by using shunt resistors or standards. These calibration verifications will be documented in the laboratory record book.

\subsection{INSTRUMENTATION TRAILER}

An instrumentation trailer will be located ten feet away from the left side of ResonantSonic drill rig. This trailer will house a power conditioner, computer system, instrument power supplies and antialiasing filters. A field 
WHC-SD-EN-TP-047, Rev. 1

generator will supply power to the power conditioner. The computer system, instrument power supplies and antialiasing filters will operate from the conditioned power.

An elevated cable tray will span the distance between the drill rig and the instrument trailer. The cable tray will carry power and signal leads to the instruments mounted on the drill rig. The signals pass through the antialiasing filters before they are digitized by the computer system. The computer system will record the output of the instruments and drive a graphical display located on the drill rig operator's control console.

\subsection{LOAD MEASUREMENT FIXTURE}

The ResonantSonic head axial force will be measured by a Load Measurement Fixture (LMF). This spool shaped piece is bolted between the output column flange and the pipe adapter flange. The upper end of the LMF is drilled and tapped to receive a 1" NPT fitting. A strain gauge bridge is installed on the exterior reduced section of the spool. The bridge leads pass through a hole drilled to intersect the axial centerline of the LMF below the NPT thread.

The output column rotates and oscillates in service. The leads are connected through the center of the output column by a hydraulic hose threaded into the top of the LMF. The other end of the lead hose is threaded into a slip ring fixture mounted on top of the ResonantSonic head. The hydraulic hose is bent at a right angle just before the connection to the slip ring fixture. This arrangement accommodates the oscillating motion of the output column. An instrument amplifier is contained within the rotating portion of the slip ring fixture. The amplifier has a shunt calibration resistor that will enable field checks of the calibration. The amplified signal is conducted across the stationary/rotating interface by the slip ring.

$A+/-120,000$ lbf calibration will be performed on a servo hydraulic load frame. The calibration data will be recorded as the load is cycled to between the positive and negative peak loads. The slip ring will be included in the circuit during the calibration.

\subsection{ACCELEROMETER}

Three LMF mounting bolts will capture an accelerometer mounting bracket. The accelerometer will be sensitive to the axial accelerations of the drill string. The leads for this instrument will follow the same path as the leads for the LMF.

The Standards Laboratory is not equipped to calibrate an accelerometer of this range. The manufacturer's calibration data will be used for these tests. Post-test verification of this calibration will be made to the limits of the available equipment's capabilities or to the maximum values measured during the tests. 
WHC-SD-EN-TP-047, Rev. 1

\subsection{EDDY CURRENT DISPLACEMENT TRANSDUCER}

An eddy current displacement transducer will be mounted in an opening in the air spring cover. This instrument will measure the displacement of the air spring piston. The piston is bolted to the top of the output column. This measurement will represent the displacement of the drill string.

The eddy current transducer is connected to a signal conditioner by a fifty foot lead. The signal conditioner will be mounted high on the mast. This is one of the few instruments that has an analog output rather than a current loop output.

This instrument will be calibrated by using a dial indicator to measure the position of the air spring. The dial indicator shall be calibrated by the Standards Laboratory within \pm 0.001 in. throughout the one inch range. A hydraulic jack, under the output column of the ResonantSonic head, will change the position of the air spring. The output of the eddy current displacement transducer will be recorded at intervals throughout the normal operating displacement of the air spring piston.

\subsection{CARRIAGE POSITION}

A twenty-five foot range magnetostrictive displacement transducer will measure the position of the ResonantSonic head carriage. The change in position, combined with the change in time will give the drilling rate.

Threaded pads will be welded at intervals along the length of the mast. Mounting brackets will bolt to the pads and position the displacement transducer parallel to the mast. The ResonantSonic head carriage will receive a mounting bracket that will position a magnet concentric to the axial centerline of the displacement transducer.

This instrument will be calibrated by a tape measure connected to the carriage. The instrument's output and position will be recorded at intervals along the length of the mast.

\subsection{OSCILLATOR MOTOR PRESSURE DROP}

Tees will be installed on the inlet and outlet of an oscillator hydraulic motor. A $\pm 3,000$ psid transducer will connect to the tees for measurement of the pressure drop across the motor. This measurement combined with oscillator RPM will give an indication of the horsepower delivered to the oscillator.

The oscillator motor differential pressure transducer will be calibrated using a dead weight pressure calibrator.

\subsection{PIPE TORQUE}

Tees will be installed on the inlet and outlet ports of the pipe rotation motors. A $\pm 3,000$ psid transducer will connect to the tees and measure the pressure drop across the rotation motors. 
A 50,000 in-1bf torque cell will mount to a fixture that is restrained from rotation by the rig's pipe wrenches. The Standards Laboratory is not equipped to calibrate an instrument of this range. The instrument will be calibrated using a shunt calibration resistor and values supplied by the manufacturer. A drum brake will couple the torque cell and the output column of the ResonantSonic head. The output of the differential pressure transducer and torque cell will be recorded as the output column is rotated and the braking force (torque) is varied. This will produce a calibration that gives engineering units of torque from the pressure drop across the hydraulic motor.

The calibration will be performed in both a dynamic (rotation of the column) and static (no column rotation) modes. This will be done to determine if there are any effects on the calibration resulting from venturi effects due to the flowing hydraulic fluid.

This braking setup also will be used to characterize the effect of torque on the output of the load measurement fixture. The output of the load measurement fixture and the torque cell will be recorded as the torque on the output column is varied.

\subsection{MAST PULLDOWN MOTOR PRESSURE DROP}

A \pm 3000 psid transducer will be connected to the inlet and outlet ports of the head carriage elevating motor. This hydraulic motor produces the thrust or pulldown on the drill string. The differential pressure transducer will be calibrated in pounds force by mounting a calibrated load cell to the LMF. A ten foot length of pipe will-be attached to the load cell. The pipe will be gripped by a braking fixture fitted to the rig's pipe wrenches. Calibration data will be recorded from the load cell and the pressure transducer while the braking force is varied during elevation and descent.

An existing $\pm 50,000$ lbf load cell will be used to calibrate the mast pulldown force. This load cell will be calibrated over a $\pm 20,000$ lbf range to give a more precise calibration than possible using the output of the LMF. The Standards Laboratory is not equipped with the means to apply the tension and compression loads required to calibrate the load cell. The load cell will be calibrated against a calibrated load frame.

\subsection{ROLLER POSITION SENSOR}

A proximity sensor will generate a pulse each time an arm mounted on a roller drive axial passes. This pulse will correspond the 3 0'clock position of the roller. This pulse should match the peak displacements under resonant conditions. The pulse will be used to measure oscillator $\mathrm{Hz}$ as well as the roller position.

\subsection{DRILL STRING ROTATION RPM}

A proximity sensor will generate a pulse each time a gear tooth in the drill string rotation drive train passes. These pulses will measure the drill string RPM. 


\subsection{FIELD MEASUREMENTS}

The life of the instruments may be limited under the service conditions imposed by the ResonantSonic drifl rig. A string of pipe will be driven into the ground before the instruments are installed. The string of pipe will be long enough to achieve resonance. This will assure that some data is recorded before any instrument failures are experienced. A11 lengths of pipe will be inspected before use to insure there are no existing cracks.

An individual data file will be generated for each length of pipe. The data file will identify the pipe by it's position in the string. The LMF output at zero load and the coupling torque will be recorded in each file header.

\subsection{INITIAL MEASUREMENTS}

The pipe will be put in resonance as the data collection system collects a limited amount of data at a high rate. The data will be reviewed before driving the remaining length of pipe into the ground. The data collection and filter parameters will be adjusted to limit the frequency content of the data as judged suitable by the initial measurements. This process may be iterated several times.

Once the data collection parameters are set, a length of pipe will be driven into the ground while varying the power and pulldown parameters. The actual increments in these parameters will be defined and refined with field experience.

A length of pipe, with a known crack, will be installed in the drill string. Data will be recorded as the cracked pipe is driven into the ground using the previously defined collection parameters. If the frequency spectrum is not affected by the cracked pipe, the data collection will be adjusted to higher rates until there is a visible indication in the spectrum. The cracked pipe will be removed from the drill string after these measurements are made.

\subsection{PIPE COUPLING}

The fatigue life of a threaded connection is influenced by the torque used to make up the connection. This is complicated in ResonantSonic drilling by the phenomena of additional turns gained by the threads when the resonant energy is applied. The magnitude of this additional make up and the resulting stress is not known.

Lengths of pipe will initially be threaded together so the shouldered surfaces just make contact. Index marks will be made across the adjoining pipe ends. The length of pipe will be unthreaded and then torqued to a lower than usual value of torque. The torque and the distance between the index marks will be recorded. This process will be repeated while incrementing the torque. These measurements will be made on a minimum of five lengths of pipe. A regression line will relate the applied coupling torque to the degrees of rotation. 
WHC-SD-EN-TP-047, Rev. 1

After each length of pipe is torqued to the string, alinement marks will be punched on the adjoining ends of the coupled pipes. The distance between the alinement marks will be recorded during the drill string extraction process. 
WHC-SD-EN-TP-047, Rev. 1

This page intentionally left blank. 
WHC-SD-EN-TP-047, Rev. 1

APPENDIX B

SOIL VIBRATION AND DISPLACEMENT TEST PLAN

W.E. Stewart

B-1 
WHC-SD-EN-TP-047, Rev. 1

This page intentionally left blank. 


\subsection{INTRODUCTION}

The vibratory drilling method consists of vibrating a drill string from 1- to 150-hertz while rotating it. The Tateral acceleration component down the string causes the formation to yield below the drill bit, thus causing the bit to advance using minimum hydrautic crowd pressure.

Vibrations in the soil will be measured from the surface down to a level of 60 feet as the drill string passes by triaxial accelerometers. The acceleration waveform data is stored and later used as input data to a subsurface structural analysis software package, which can accommodate any subsurface model of a real structure.

\subsection{GENERAL DESCRIPTION}

\subsection{TEST OBJECTIVES}

Provide digitized waveform data in DOS files which will indicate soil vibration effects on subsurface structures which are induced by ResonantSonic drilling operations. Additionally, determine soil displacements caused by ResonantSonic drill operations.

\subsection{TEST METHOD}

Two, 4-inch $X$ 60-foot casings are placed 10 feet apart into the soil stratigraphy which best represents the subsurface conditions at the actual subsurface waste disposal structure or storage tank. Each 4-inch casing has 7 triaxial accelerometers installed at 10-foot intervals. A third casing is used for measuring soil displacements in vertical and horizontal directions. The final product is a data set which allows the analysis to use any subsurface structure model, along with the variable distance from the drilling operation to the structure, in order to optimize the combination to minimize induced stresses on the structure.

The test on the ResonantSonic dritl is to be conducted in a vertical $\left(90^{\circ}\right)$ position from the surface or horizontal $\left(0^{\circ}\right)$. The test is currently planned to begin with drilling at a distance of 30 feet from the test array and proceeds according to the following: 20-feet, 10-feet, 5-feet, and optionally at 3 -feet. The actual distances from the test array may vary from these values. Any variances will be recorded in the test logs. Soil displacements are recorded and accelerations are stored in computer files for each distance. The drilling operation and data collection is stopped when the hole at a particular distance is drilled to 60 foot in depth. The drilling operation is then moved to a new location which is closer to the test array per the previously listed distances. Drilling and data collection are repeated at the new location. This iteration is repeated multiple times until the drilling operation is in near proximity to the test array. Thus, a generic set of data is generated which can be applied to any subsurface structure modeled and analyzed in that type of soil media. 


\subsection{PRE-TEST}

In order to gain baseline data and other configuration information, a pre-test is conducted. The pre-test is designed to allow the instrumentation and scopes to be set up and initialized. In addition, the pre-test is used to determine the initial distance the drill is placed from the test stand for the first test hole. From this information, the incremental distance for each step approaching the test array is determined.

The pre-test covers the following sections of this overall test: 4.0 Test Condition Limits; 6.0 Facilities, Equipment, and Materials;

7.0 Safety; 10.0 Personnel Requirements; and 12.0 Procedure.

\subsection{TEST ITEM IDENTIFICATION}

- 6 - IBM compatible PC's

- 22 - Rapid Systems R1200 digital oscilloscopes with software

- 14 - Triaxial accelerometers with bladders

- 1 - nitrogen pressure regulation system

- 1 - extensometer/inclinometer casing 60-foot long

- 1 - extensometer. measuring device

- 1 - inclinometer device

- Various fittings, couplings, connectors, cables, etc.

\subsection{TEST CONDITION LIMITS}

Outside the realm of the drilling operation itself, the main concern which could abort the test would be a computer or power failure.

\subsection{INSTRUMENTS AND CALIBRATION}

The following instrumentation systems are set and/or calibrated per manufacturers instructions:

- 14 - Triaxial accelerometers

- 1 - inclinometer device.

The following instrumentation systems are set per manufacturers instructions:

- 22 - Rapid Systems R1200 digital oscilloscopes

- 1 - extensometer measuring device. 
The test accuracy of the geophone is $\pm 10 \%$; the accuracy is $\pm 10 \%$; the maximum allowable error is $\pm 20 \%$. The $L$-axis has an error of $-2.6 \%$, the $V$-axis has an error of $-6.7 \%$, and the $T$-axis has an error of $+1.1 \%$. These errors are within allowable limits. package.

The instrument calibration sheets will be attached to the completed test

\subsection{FACILITIES, EQUIPMENT, AND MATERIALS}

The test facility is a NEPA approved site which is located near the fire station between the 200 East and 200 West areas. A mobile trailer houses the computers and test equipment. The ResonantSonic drill rig will be mobilized to the test site with appropriate casing sizes, couplings, etc.

\subsection{SAFETY}

An appropriate safety analysis was completed to cover the drilling operations. The worst case safety situation for testing, stems from the electrical arena which are lower power standard devices.

All nonessential personnel will be excluded from work areas. Observer areas will be designated and controlled.

A pre-job safety meeting will be conducted prior to starting the test.

\subsection{MAINTENANCE AND FAILURES}

The drilling operation should progress without the drilling operation stopping from the surface to the predetermined depth of 60 feet, while the data acquisition is occurring. Thus, each drilling operation at each 1 isted distance needs to be followed through to completion. A maintenance problem or failure in equipment may require a restart of the test. The field team leader is responsible for the stopping or starting of all tests. Stopping of the drilling operations (e.g., required maintenance or end of work day) and related test can readily be accommodated between the incremental distance drilling operations.

Test resumption requires starting at the ground surface and completing a full depth test hole, unless circumstances dictate otherwise. 
WHC-SD-EN-TP-047, Rev. I

\subsection{TEST DATA}

Data taking collection is as follows:

- The vibration data is in the form of digitized waveform DOS data files made by each triaxial accelerometer channel.

- The vibration waveforms are processed by digital oscilloscopes which are triggered to begin data acquisition in unison when the drilling operation begins.

- The waveform files are tracked using a data sheet which shows starting/completion times, and tracks the file name in relation to each channel of each triaxial accelerometer.

- The waveforms are displayed on monitors, and can be printed out if necessary.

- Soil vertical and horizontal displacements are recorded on appropriate logs and, if necessary, transferred to a spread sheet. Displacement plots are then generated from this data.

- All of the pertinent data collected, including plots and any charts, are transmitted to the Hanford Technical Services (HTS) Division. The level of security is determined by the HTS Group.

\subsection{PERSONNEL REQUIREMENTS}

Apart from the test setup and equipment mobilization, the data acquisition will require 2 persons. The drilling crew will consist of 3 personnel not including any site supervisory personnel.

\subsection{WITNESSES}

Observers, inspectors, user and vendor representatives, and others are to be notified approximately 5 days prior to the test. Any visitors to the site are required to sign a visitors log. 
WHC-SD-EN-TP-047, Rev. 1

\subsection{PROCEDURE}

\subsection{INSTRUMENTATION/EQUIPMENT}

- 6 - IBM compatible PC's

- 22 - Rapid Systems R1200 digital oscilloscopes

- 14 - Triaxial accelerometers

- 1 - extensometer measuring device

- 1 - inclinometer device

- 1 - nitrogen pressurization system.

\subsection{NOTES AND PRECAUTIONS}

- Establish clear lines of communications with drilling crew.

\subsection{TEST REQUIREMENTS/PREREQUISITES}

- 2, 4-inch carbon steel, schedule 40, threaded joints, and open casings installed to 60 foot depth

- Inclinometer/extensometer plastic casing installed to 60 foot depth

- Inclinometer and extensometer instruments available

- 7-accelerometers installed in each 4-inch casing using nitrogen bladder system. Cables routed and bundled as appropriate and connected to digital oscilloscopes

- 6 - IBM compatible PC's connected to 22 - digital oscilloscopes.

- Data acquisition system operable and housed inside enclosure

- ResonantSonic drill rig and necessary ancillary equipment available and positioned at a distance of 30 feet from test array

- Data sheets available.

\subsection{RESONANTSONIC VIBRATION TEST}

1. Energize the data acquisition system.

2. Set sampling rate on systems to at least twice the highest expected drill frequency.

3. Ensure scope software is set up properly by observing traces on monitor for each channel (i.e., each axis).

4. Start drilling operation and simultaneously trigger all scopes to commence data acquisition.

5. Continue drilling and data acquisition until drilling is stopped to add drill rod or casing.

6. Terminate data acquisition and drilling.

7. Add drill rods or casings to drill string.

8. Repeat steps 4 through 8 until 60 -foot depth is reached. 
9. Withdraw ResonantSonic drill and reposition at new incremental location nearer test array.

10. Repeat steps 4 through 9 listed above. If test is suspended, attempt to stop at this point. Restart test at this point, if possible. Note actions in logs/comment sheets.

Note: Test performance iterations will be documented in the test logs with appropriate signoffs \& comments.

\subsection{TEST SITE RESTORATION}

All removable instrumentation will be removed from site. Subsurface well, extensometer, and inclinometer casing removal is at the discretion of the HTS Division. All holes will be abandoned in accordance with WAC 173-160.

\subsection{DISPOSITION OF TEST ITEMS}

Electronic components will be stored in appropriate areas. Down hole devices are to be removed and stored. The decision to leave in-ground casing in place is deferred to the HTS Division.

\subsection{TEST LOGS/DATA SHEETS}

Test logs are maintained to show the actual procedural steps and follow the steps of Section 11. Test commencement, restarts, suspensions, notes, and comments are chronologically entered and signed off in the log (a controlled field logbook).

Data Sheets are attached to the back of the test plan package. They indicate which DOS waveform file corresponds to each channel of each triaxial accelerometer, including time, date, and any appropriate notes. 
WHC-SD-EN-TP-047, Rev. 1

\section{APPENDIX C}

RESONANTSONIC DEMONSTRATIONS SCHEDULE 
WHC-SD-EN-TP-047, Rev. 1

This page intentionally left blank. 
WHC-SD-EN-TP-047, Rev. I

ResonantSonic Demonstrations Schedule. (sheet 1 of 2)

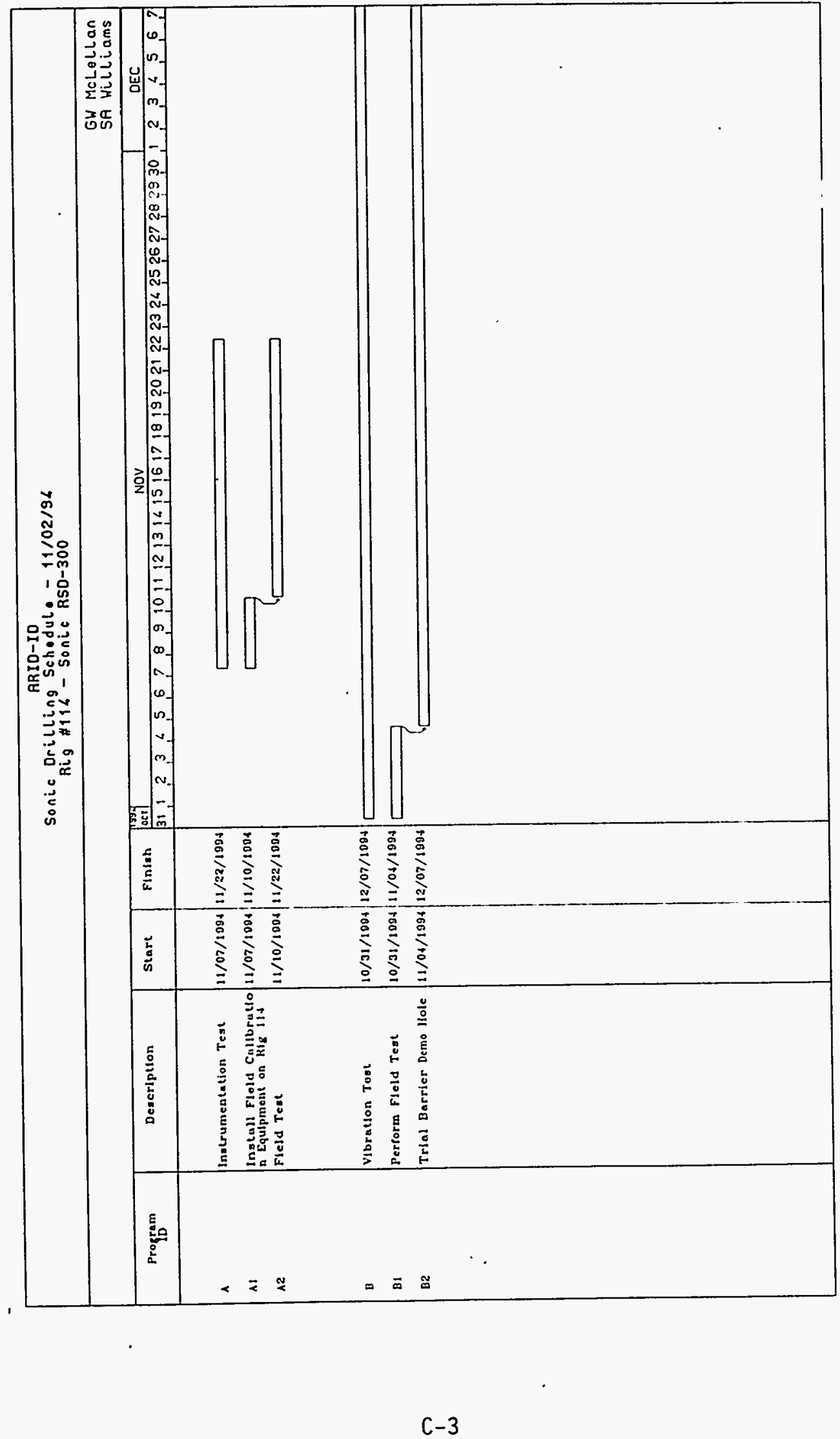


WHC-SD-EN-TP-047, Rev. 1

ResonantSonic Demonstrations Schedule. (sheet 2 of 2)

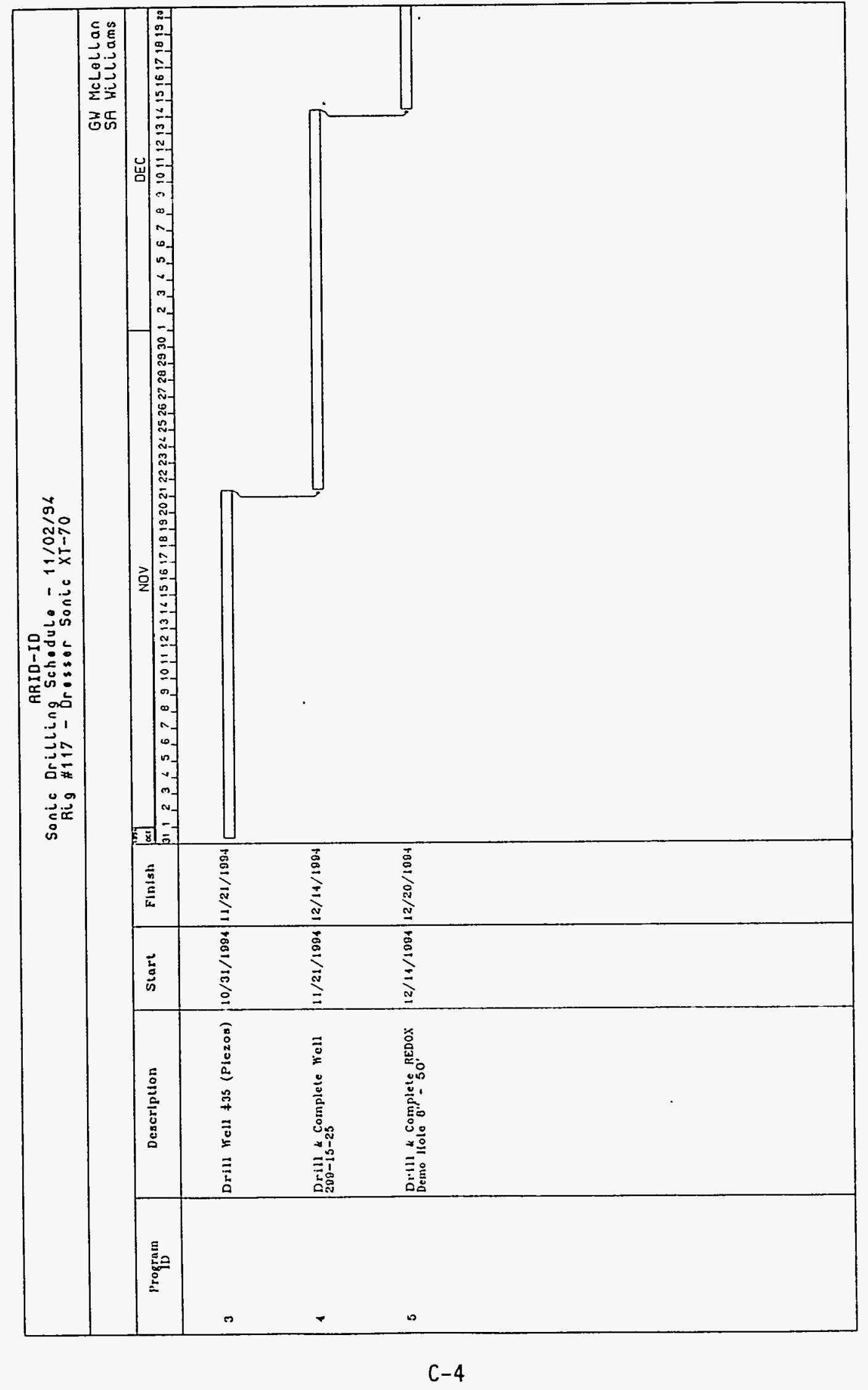


WHC-SD-EN-TP-047, Rev. 1

DISTRIBUTION

Number of copies

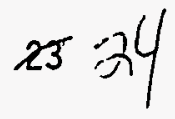

\author{
Westinghouse Hanford Company \\ Richland, Washington
}

L. 0. Amos (6)

H6-30

G. T. Berl in

LO-18

T. M. Brouns

K6-80

B. R. Cassem

$\mathrm{H} 6-30$

M. C. Hagood

$\mathrm{H} 6-04$

G. W. McLeTlan (3)

H6-30

L. R. Richterich

$\mathrm{H} 6-30$

W. E. Stewart

D. M. Squier

$\mathrm{H} 6-30$

M. A. Tredway

L6-13

W. R. Thackaberry

$\mathrm{S} 2-42$

B. G. Tuttle

CRADA File

H4-16

N3-06

H6-30 Central Files ( 2 )

L8-04

OSTI (2)

L8-07 


\begin{tabular}{|c|c|c|c|c|c|}
\hline \multirow{3}{*}{ 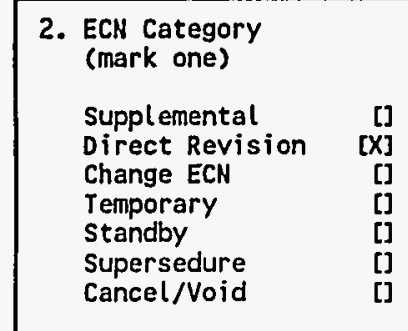 } & \multicolumn{4}{|c|}{$\begin{array}{l}\text { 3. Originator's Name, Organization, MSiN, and Telephone No. } \\
\text { L.R. Richterich, } 8 \mathrm{H} 300, \mathrm{H} 6-30,373-7540\end{array}$} & $\begin{array}{l}\text { 4. Date } \\
11 / 14 / 94\end{array}$ \\
\hline & \multicolumn{4}{|c|}{$\begin{array}{l}\text { 5. Project Title/No./Hork Order No. } \\
\text { TTP421103 }\end{array}$} & $\begin{array}{l}\text { 7. Approval Designator } \\
\text { SQ }\end{array}$ \\
\hline & \multicolumn{2}{|c|}{$\begin{array}{l}\text { 8. Document Numbers Changed by this ECN } \\
\text { (includes sheet no. and rev.) } \\
\text { WHC-SD-EN-TP-047, Revision } 0\end{array}$} & \multicolumn{2}{|c|}{$\begin{array}{l}\text { 9. Related ECN No(s). } \\
\qquad N / A\end{array}$} & $\begin{array}{l}\text { 10. Related PO No. } \\
\text { N/A }\end{array}$ \\
\hline $\begin{array}{l}\text { 11a. Modification Work } \\
\text { [] Yes (fill out } 8(k \text {. } \\
{[X] \text { No (NA Blks. } 11 b \text {, }} \\
{[11 c, 11 d)}\end{array}$ & $\begin{array}{l}\text { 11b. Hork Package } \\
\text { No. } \\
\text { N/A } \\
\qquad\end{array}$ & \multicolumn{2}{|c|}{$\begin{array}{l}\text { 11c. Modification Hork Complete } \\
\text { N/A }\end{array}$} & \multicolumn{2}{|c|}{$\begin{array}{l}\text { 11d. Restored to Original Condi- } \\
\text { tion (Temp. or Standby ECN only) } \\
\text { N/A }\end{array}$} \\
\hline \multicolumn{6}{|c|}{$\begin{array}{l}\text { 12. Description of change } \\
\text { Revision of text materials which includes testing criteria, test locations, and } \\
\text { description of work to be performed for FY95 testing of the ResonantSonic Drilling } \\
\text { method. }\end{array}$} \\
\hline $\begin{array}{l}\text { 13a. Justification } \mathrm{Cr} \\
\text { (mark one) }\end{array}$ & Criteria Change $\quad[X]$ & \multicolumn{2}{|c|}{ Design Improvement } & \multicolumn{2}{|c|}{$\begin{array}{ll}\text { Envi ronmental } & {[]}\end{array}$} \\
\hline As-found $\quad[] \quad \mathrm{Fa}$ & \multicolumn{3}{|c|}{ Facilitate Const. [] Const. Error/Omission } & \multicolumn{2}{|c|}{ Design Error/Omission [] } \\
\hline \multicolumn{6}{|c|}{$\begin{array}{l}\text { 13b. Justification Details } \\
\text { This is a yearly revision of the integrated test plan for the ResonantSonic drilling } \\
\text { method as required per the VOC-Arid Demonstration Operations. This test plan is } \\
\text { revised yearly to provide testing guidelines for field demonstrations of innovative } \\
\text { drilling technology. }\end{array}$} \\
\hline \multicolumn{4}{|c|}{$\begin{array}{l}\text { 14. Distribution (include name, MSIN, and no. of copies) } \\
\text { See attached distribution Tist. }\end{array}$} & \multicolumn{2}{|c|}{ 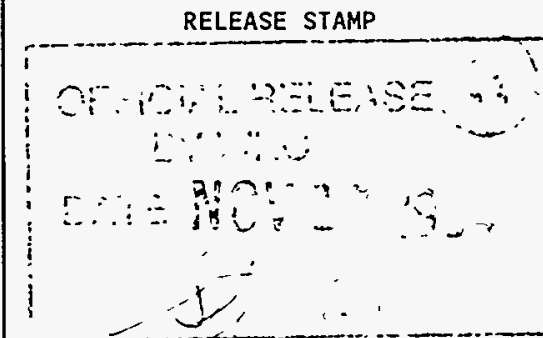 } \\
\hline
\end{tabular}

A-7900-013-2 (06/94) GEF095 


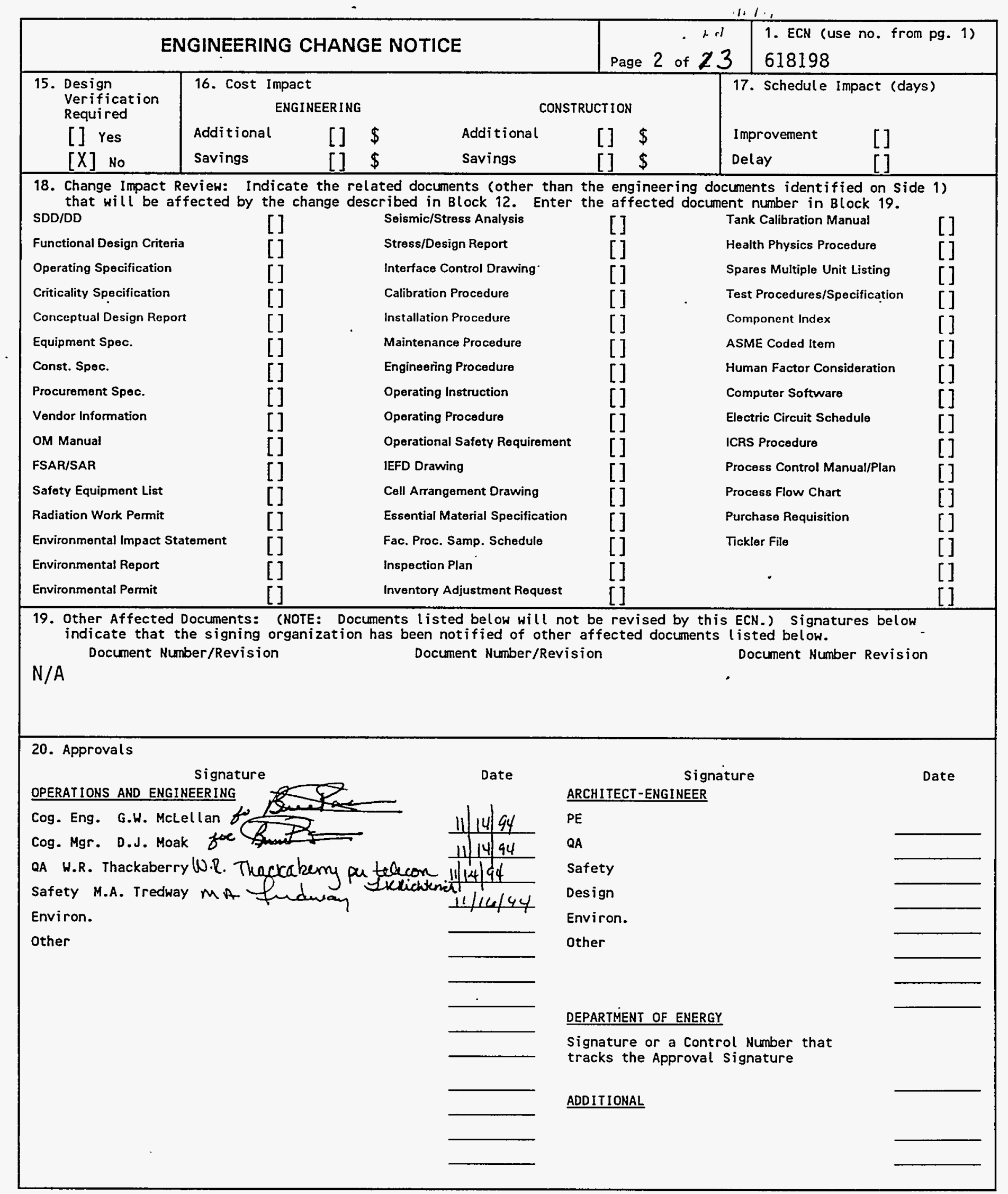




\begin{tabular}{|l|l|}
\hline $\begin{array}{l}\text { 2. To: (Receiving Organization) } \\
\text { Distribution }\end{array}$ & $\begin{array}{l}\text { 3. From: (originating Organization) } \\
\text { Geotechnology Engineering } \\
\text { Services }\end{array}$ \\
\hline 5. Proj./Prog./Dept./Div.: & $\begin{array}{l}\text { 6. Cog. Engr.: } \\
\text { Grilling Technology }\end{array}$ \\
\hline 8.W. McLellan \\
\hline
\end{tabular}

4. Related EDT No.:

600218

8. Originator Remarks:

Please approve and sign by November 4, 1994.

\begin{tabular}{|l} 
\\
\hline 11. Receiver Remarks:
\end{tabular}

(

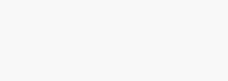

\section{Purchase Order No.: $\mathrm{N} / \mathrm{A}$}

9. Equip./Component No.: $N / A$

10. System/Bldg./Facility: $\mathrm{N} / \mathrm{A}$

12. Major Assm. Dwg. No.: $N / A$

13. Permit/Permit Application No.: $N / A$

14. Required Response Date: November 4, 1994

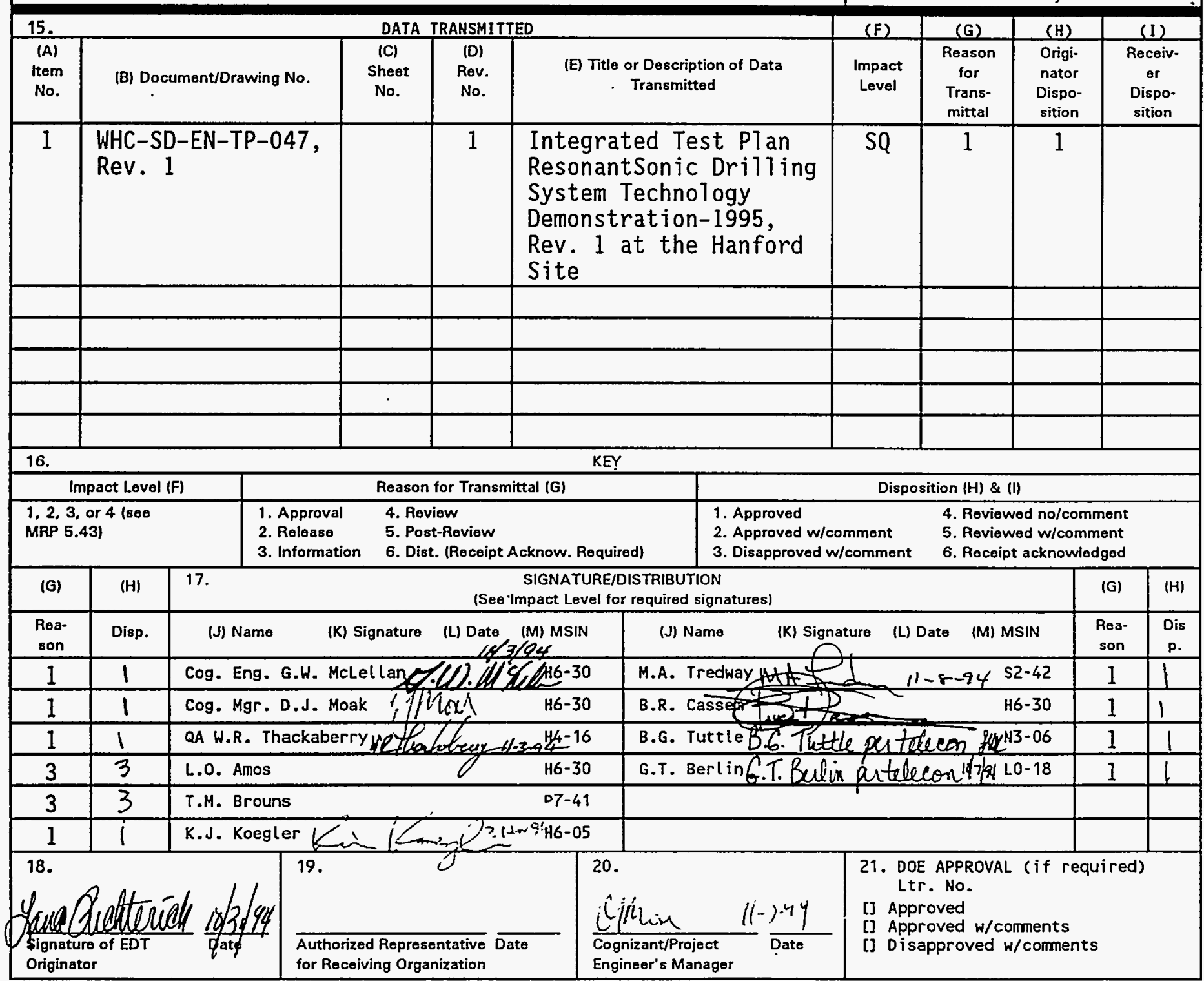




\section{RELEASE AUTHORIZATION}

Document Number: WHC-SD-EN-TP-047, REV. 1

Document Title: $\quad$ Integrated Test Plan ResonanSonic Drillilng System

Technology Demonstration-1995, at the Hanford Site

Release Date: $\quad 11 / 16 / 94$

\section{This document was reviewed following the procedures described in WHC-CM-3-4 and is:}

\section{APPROVED FOR PUBLIC RELEASE}

WHC Information Release Administration Specialist:

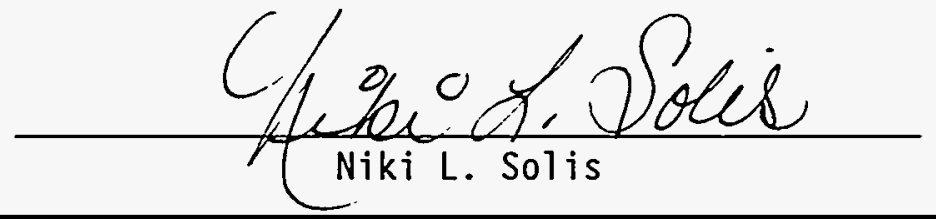

$11 / 16 / 94$

TRADEMARK OISCLAIMER. Reference herein to any specific comercial product, process, or service by trade name, trademark, manufacturer, or otherwise, does not necessarily constitute or imply its endorsement, recommendation, or favoring by the United States Government or any agency thereof or its contractors or subcontractors.

This report has been reproduced from the best available copy. Available in paper copy and microfiche. Printed in the United States of America. Available to the U.S. Department of Energy and its contractors from:

U.S. Department of Energy

office of Scientific and Technical Information (OSTI)

P.0. Box 62

Oak Ridge, TN 37831

Telephone: (615) 576-8401

Available to the public from:

U.S. Department of Commerce

National Technical Information Service (NTIS)

5285 Port Royal Road

Springfield, VA 22161

Telephone: (703) 487-4650 


2. Title
Integrated Test P1an ResonantSonic Drilling System
Technology Demonstration-1995, Rev. I At the
Hanford Site

5. Key Words

ResonantSonic, Sonic, Drilling, Technology, Cooperative Research and Development Agreement, (CRADA), VOC-Arid ID

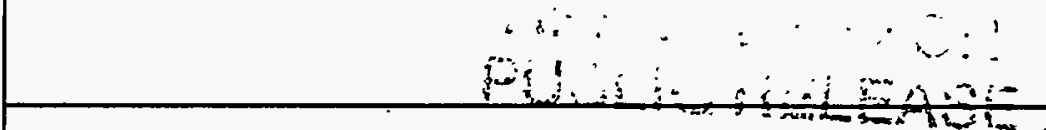

\section{Abstract}

\section{$11 / 16 / 94 / 20$ ber}

3. Number

WHC-SD-EN-TP'047
4. Rev No.

1

This integrated test plan describes the second phase of field demonstration tests of the ResonantSonic SM1 drilling system. Earlier tests conducted in 1991-92 demonstrated the potential of this drilling system and also highlighted several areas where component and method improvement were necessary. As a result, a Cooperative Research and Development Agreement (joint research and development project between goverment and private industry) with Water Development Corporation of Woodland, California was formed.

The Phase 1 test program was initiated on July 19, 1993, and was completed at the end of Fy1993. The Phase 2 program began during June 1994 and testing will continue through the 1995 calendar year. Two main purposes of this demonstration are (1) to continue testing the ResonantSonic drilling system compatibility with the waste site characterization programs at the Hanford site, and (2) to transfer this method for use at the Hanford site, other government sites, and the private sector.

McLellan, G. W. and B. W Volk, 1993, Integrated Test Plan for the Sonic Drilling Method on the Hanford Site FY 1993, WHC-SD-EN-TP-028, Rev. 0, Westinghouse Hanford Company, Richland, Wašhington.

8. PURYOSE AND USE OF DOCUMENT - This document was prepares for use with the U.S. Department of Energy arid its contractor It is to be 4 ad only to perform, direct, or integrate work under U.S. DE artment of Energy contracts. This document $s$ not approved for publ \& release until reviewed.

PATENT STAY S - This document copy, since advance of pa ent clearance, is made availabl for use in erformance of work under contracts with the U.S. Department Energy. This document $;$ not to be publis'ed nor its contents otheh ise disseminated or $y$ - $d$ for pucposes o ler than specified above bet e patent approval for such re ease use has been secured, upon ree iest, from the atent Counsel, is Department of Energy Field Office, Bichland,

DISCLAIMER - This repor was prepared as an a cout of work sponsored by an agency of th inited States Governm it. R i ther the United States Government nofy agency thereof hor any their employees, nor any of thr $r$ c. tractors, subco, tractors of their employees, makes any war anty, ex ress or imp' ed, or assumes any legal liability or resp, isibility fhe accuracy, completeness, or any third party's use or the results such use of any information, apparatus, product or process disclose or represents that its use would not infringreprivately owned right. Reference herein to any specific commer fal product, process, of service by trade name, trademark, mr ufacturer, or otherwise, loes not necessarily constitute 9 imply its endorsement, recomment tion, or favoring by the Unite States Government or any agend thereof or its contractols or subcontractors. The views and op hions of authors expressed herein do not necessarily state or reflect those of the United States Government or any agency thereof.

9. Impact Level SQ
10.

RELEASE STAMP

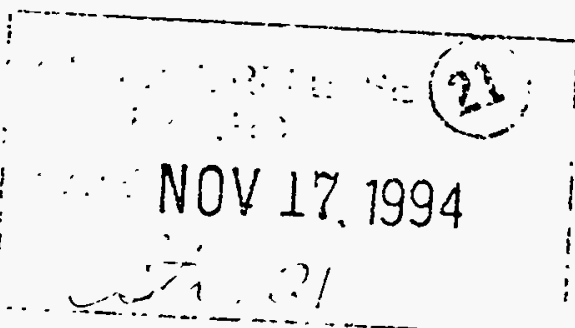


RECORD OF REVISION

(1) Document Number

WHC-SD-EN-TP-047

Page 1

(2) Title

Integrated Test Plan ResonantSonic Drilling System Technology Demonstration-1995, at the Hanford Site

CHANGE CONTROL RECORD

\begin{tabular}{|c|c|c|c|}
\hline \multirow{2}{*}{ (3) Revision } & \multirow{2}{*}{ (4) Description of Change - Replace, Add, and Delete Pages } & \multicolumn{2}{|c|}{ Authorized for Release } \\
\hline & & (5) Cog. Engr. & (6) Cog. Mgr. Date \\
\hline & (7) & & \\
\hline 0 & Per EDT \#600218 & 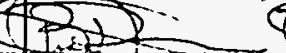 & $31>$ \\
\hline 1 RS & $\begin{array}{l}\text { Revision } 1 \text { per ECN \#618198. - Complete } \\
\text { Revision }\end{array}$ & 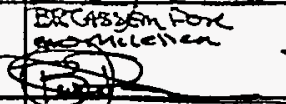 & Des resen + D MEAK \\
\hline & & & 7 \\
\hline & & & \\
\hline & & & \\
\hline & & & \\
\hline & & & \\
\hline & & & \\
\hline & & & \\
\hline & & & \\
\hline & & & \\
\hline & & & \\
\hline & & & \\
\hline & & & \\
\hline & & & \\
\hline & & & \\
\hline & & & \\
\hline & & & \\
\hline & & & \\
\hline & & & \\
\hline & & & \\
\hline & & & \\
\hline & & & \\
\hline & & & \\
\hline & & & \\
\hline & & & \\
\hline & & & \\
\hline & & & \\
\hline & & & \\
\hline & & & \\
\hline & & & \\
\hline
\end{tabular}

